\title{
MARINE SEDIMENT CHARACTERISTICS AT KARIMUN JAVA SEA BASED ON STRATIGRAPHIC PROFILE ANALYSIS, TOTAL SUSPENDED SOLID (TSS) AND GRAIN-SIZE ANALYSIS (GRANULOMETRY)
}

\author{
Suryantini $^{1)}$, Aris Ismanto ${ }^{2)}$, Indarta Kuncoro Aji ${ }^{1)}$, \\ Dwi Fajar Saputri ${ }^{1)}$, and Helfinalis ${ }^{3)}$ \\ ${ }^{1)}$ Applied Geology Research Division, Geology Study Program, Faculty of Earth Sciences and \\ Technology, Institut Teknologi Bandung, Jl. Ganesha 10, Bandung 40132; \\ email: suryantini@gc.itb.ac.id \\ ${ }^{2)}$ Oceanography Study Program, Diponegoro University, Jl. Prof. Sudharto SH, Semarang. \\ ${ }^{3)}$ Research Centre for Oceanography (P2O), Indonesian Institute of Sciences \\ Jl. Pasir Putih 1, Ancol Timur, 14430
}

\begin{abstract}
A sedimentology survey was conducted during "Pelayaran Kebangsaan" research activities with a marine vessel of "Baruna Jaya VIII" in Karimun Java Sea. The objectives of the research were to determine the characteristics of marine water and its sediment, which are important control for coral reef growth in the study area. The survey acquired samples of Total Suspended Sediment (TSS) and gravity coring. Several analyses were then carried out on those samples; TSS analysis to determine the amount of suspended sediments in sea water that reflect the water quality for marine ecology, stratigraphic profile and sediment thickness pattern analyses to determine the sources of sediment, and grain-size analysis based on granulometry to determine deposition energy and grain-size distribution in the area. Those analyses were both conducted on-board Baruna Jaya VIII research vessel and P2O LIPI laboratory in Jakarta. The results showed that in Java Sea nearby Karimun Java Islands, the sediment supply came from the surrounding islands. Two sedimentary units were found in this area. The first units has thickness of tens centimeter from sea bed surface. It is characterized by grayish green color, grain size variation from clay to coarse sand, soft or low density and abundance with shells. The second unit is located beneath the first one, indicated by sharp contact. It is characterized by brownish color, higher density resembling the density of rock, less compacted and can be broken easily by hand, with occasionally thin carbon lenses or remnant of decomposed vegetation, and less shell or fossil At sea surface, TSS distribution shows value between 0.018 and $0.034 \mathrm{gr} / \mathrm{l}$, with average of $0.025 \mathrm{gr} / \mathrm{l}$, whereas at near bottom sea, it ranges between 0.024 and 0.030 $\mathrm{gr} / \mathrm{l}$, with average value of $0.027 \mathrm{gr} / \mathrm{l}$. The granulometry shows that more than $50 \%$ of sediment is characterized by the abundance of grain size greater than 3 phi. It suggest that sea water around Karimun Java Islands was clear and the current was relatively calm. These conditions were relatively stable for a long time span. Those sea characteristics were important for successful growth of coral reefs and its complementary marine biotas. However, further studies and researches based on chemical and physical characteristics of sea water, and plankton and microbiology variation and abundances are necessary to confirm those presuppositions.
\end{abstract}

Keywords: total suspended solid, gravity coring, stratigraphic profile, granulometry, Karimun Java Sea 


\section{INTRODUCTION}

Karimun Java Island is located in the northern off-shore of Central Java Province (Figure 1). Geographically, the islands are located significantly far (about $100 \mathrm{~km}$ ) to the north from Java mainland Island, and to the south from Kalimantan mainland Island (about 300 $\mathrm{km}$ ). Therefore, the sea around these islands mainly receive sediment supplies from the surrounding islands, as it is indicated by white to light gray color circling every island, shown in Figure 1. The figure is image of Band $1(0.45-0.52$ $\mu \mathrm{m}$ ) from Landsat 7 ETM+ (acquired in
2006), which is commonly used in coastal water mapping and marine sediments studies (Lillesand and Kiefer, 1994).

The amount of materials and its sedimentation process will affect the successful growth of coral reef and other marine biotas. Generally, the environment with clear water or with TSS less than $10 \mathrm{mg} / \mathrm{l}$ and sedimentation rate appear to be on the order of $10 \mathrm{mg} \mathrm{cm}^{-2}$ $\mathrm{d}^{-1}$ or less (Rogers, 1990), relatively calm current, and where the sun light can penetrate the water optimally, is the preferred condition for the coral reef ecology.

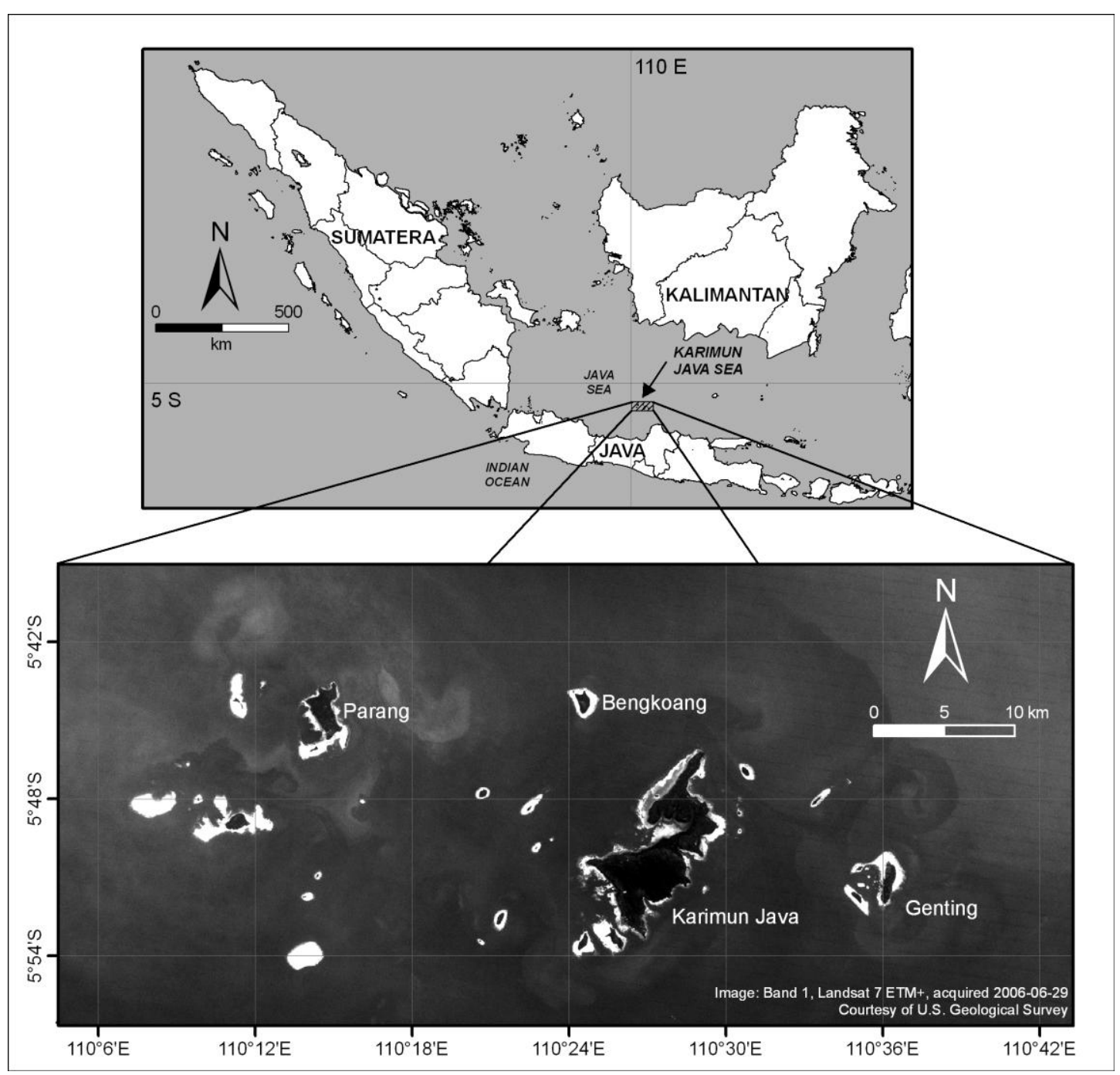

Figure 1. Karimun Java Sea and its surrounding small islands 
Sedimentation and marine suspension researches are useful for assessing the ocean condition for coral reef growth and also in monitoring ocean pollution. Rogers (1990), had reviewed the effects of sedimentation on corals reef growth, and suggested that high sediment loads may lower the diversity of reef, lower the percent cover, lower the growth rates of coral species, smaller coral colony or larger coral colony, an upward shift in depth zonation, and a greater abundance of branching forms. Several field observations have confirmed a relationship between suspended sediment levels and coral distributions in a variety of geographic locations including: the Virgin Islands (Rogers, 1983; Hubbard et al., 1987), Fanning Island (Roy and Smith, 1971), Puerto Rico (Acevedo and Morelock, 1988), Florida (Hubbard and Pocock, 1972, Rice and Hunter 1992), Costa Rica (Cortes, 1990), Jamaica (Dodge et al., 1974), and Taiwan (Hsieh, 1995).

Common method to recognize sedimentation and marine suspension include analysis of Total Suspended Solid or Sediment or shortly called TSS (Rice and Hunter, 1992; Hwey-Lian Hsieh, 1995), granulometry analysis (Hubbard and Pocock, 1972; Hsieh, 1995; Rodgers 1990) and analysis of rate of sedimentation (Rodgers, 1990)

In accordance with the above point of view, a marine sediment research in Karimun Java Sea has been conducted by Directorate of High Education under the Ministry of Education of Indonesia (DIKTI - Mendiknas) in collaboration with Center of Ocean Research under Indonesian Institute of Science (P2O LIPI) using Baruna Jaya VIII research vessel. The research was carried out for 4 days, in April 25-28, 2009, and acquired 13 samples.

The aim of the research were to determine the characteristics of marine water and its sediment based on the Total Suspended Sediment (TSS) and sediment distribution at the Karimun Java Sea floor. The result of these research activities can be used and cited by other related research concerning sediment parameter, such as research on biota and chemical content within sediment and sea water in this area.

\section{METHOD}

Sediment sample acquisition in Karimun Java Sea consisted of 13 observation points or stations, shown in Figure 2. Digital Global Positioning System (DGPS) on board of Baruna Jaya VIII vessel was used in real time to obtain the coordinate of samples location.

Two types of samples were acquired during the survey: gravity core and Total Suspended Sediment (TSS) samples.

\subsection{Gravity core samples}

In gravity core sampling, sediment samples were acquired using PVC pipe which is cement-coated at one end to serve as a gravity-balanced load (Figure 3). Sample acquisition process was carried out by dropping the pipe into sediment location under the ocean water. Since the free falling of the pipe into the sediment were only controlled by the gravity force of heavy pipe, the depth of sampling process are limited by the softness of sediment which can be penetrated by the weight of cement balance-load PVC. This kind of sampling method also limit the number of sample acquired during the survey. 


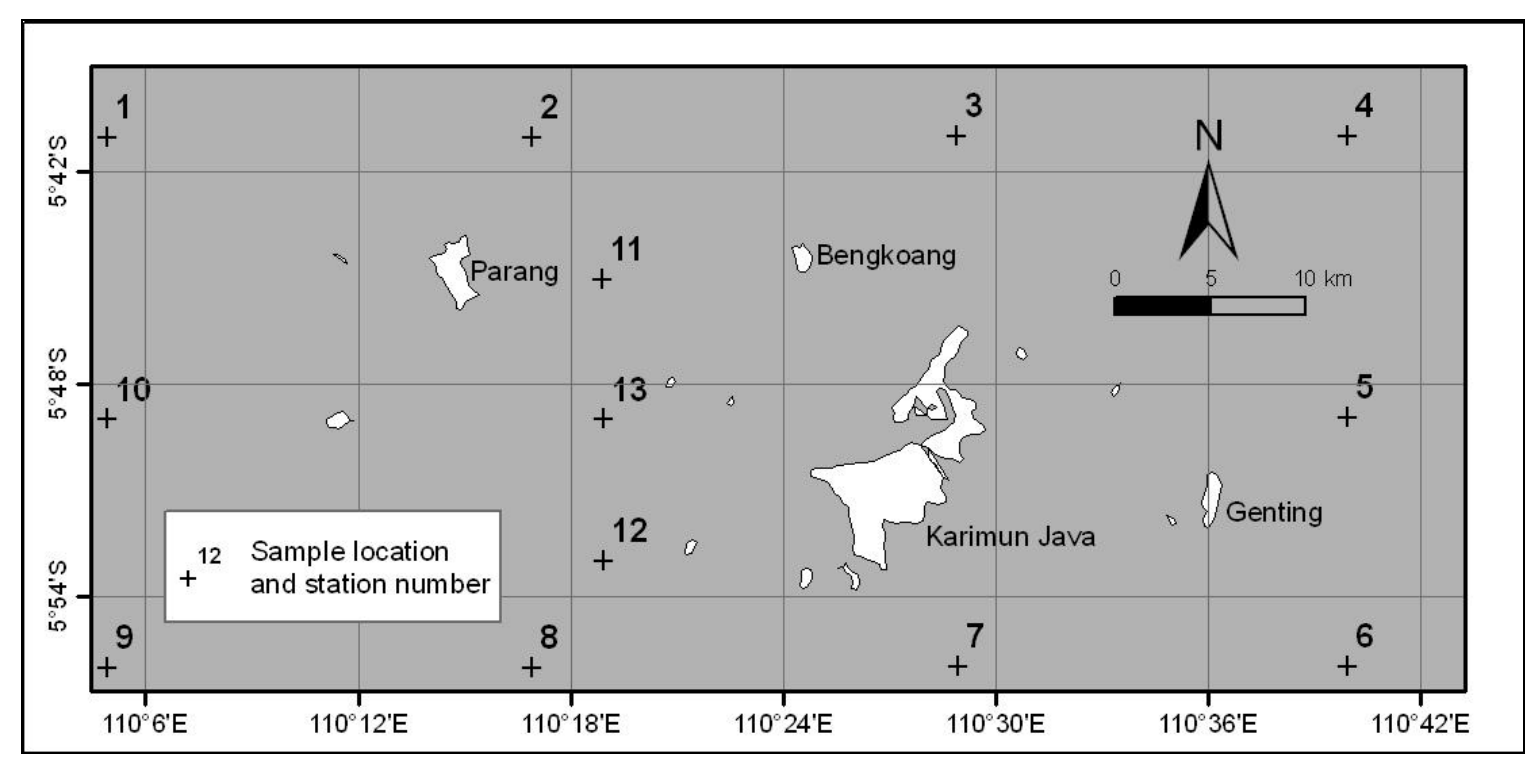

Figure 2. Sample locations.

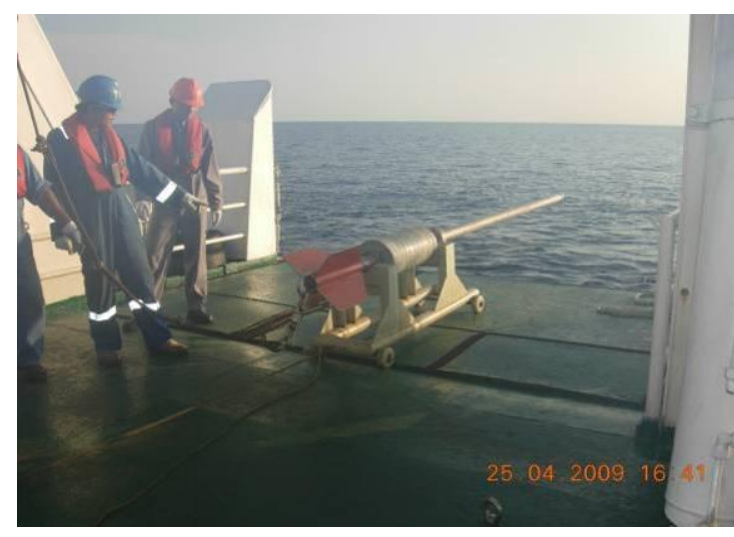

Figure 3. Gravity core sample tool

In gravity coring, the sample was split into two parts, following the diameter of the pipe, along the depth of sampling (Figure 4). The cross-cut sample obtained from this split provides a clear view of surface to certain depth sediment profile information and its variation within the profile. A profile examination was carried out at every lithological change, which includes description and identification on color, grain size, sedimentary structure, fossil type and its variation and abundances. A lithological change was marked and classified by changes in its color, composition, texture, and grain structure.

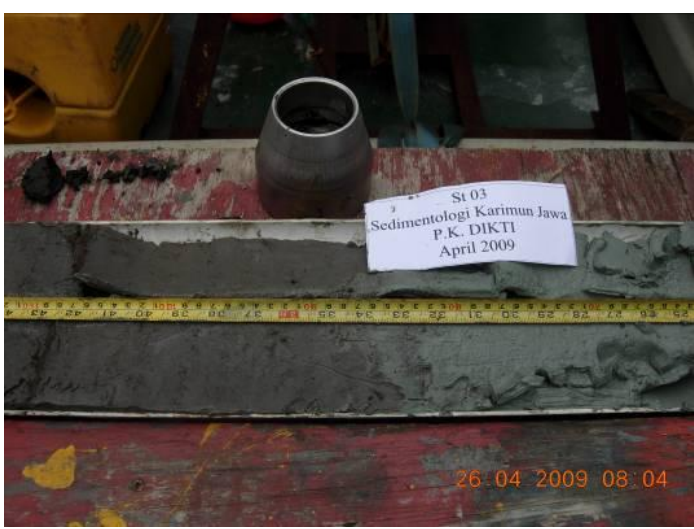

Figure 4. Sediment from gravity core sample

A stratigraphic column from each core sample was then generated based on those observations and descriptions. This stratigraphic column showed the depth of paleosoil and its recent sediment thickness, and later be used to construct distribution map of paleosoil depth and recent sediment thickness.

Furthermore, at every lithological change in a core, a total of 200-300 gram sample was collected for grain size analysis (granulometry) that would be conducted at P2O LIPI laboratory in Jakarta. In the laboratory, the samples are sieved with mesh $8,4,2,1,0.5,0.250$, $0.125,0.063$ and smaller than $0.063 \mathrm{~mm}$. 
The sieved samples were then dried and weighed to determine weight percent and its classification name according to Shepard Triangulation (1954). The sieve size or also called phi will be plotted against cumulative weight percentage in arithmetic probability plot for granulometry analysis (Bassilie dan Tanner, 1995), whereas the name of the sediment according to Shepard Triangulation (1954) was used for the name of the unit in the stratigraphic profile analyses.

\subsection{Total Suspended Sediment (TSS) sample}

In TSS sampling method, one liter of sea water samples was acquired using niskin at near surface and sea floor depth for each station. A $250 \mathrm{ml}$ water sample was then filtered using 20 micron filter paper (Figure 5) which was weighed prior to measurement. The 20 micron filter was used in order to filter sediment particle with size greater than $0.02 \mathrm{~mm}$.

As soon as the filtering process was finished, the filter paper was dried inside a $60^{\circ} \mathrm{C}$ oven. After that the filter paper was weighed again. The weight difference before and after filtering was the weight of TSS. The remaining sediment in filter paper was called Total Suspended Sediment or TSS. The value of TSS was subsequently plotted in a map to visualize its spatial distribution.

\section{RESULT AND DISCUSSION}

\subsection{Marine Sediment Characteristics}

Generally, Karimun Java Sea sediment profile can be divided into two stratigraphic units, based on lithology characteristics, mainly on its relative density or soil hardness property which may reflect the age difference (Figure 6). The stratigraphic profile of each sample of gravity coring is presented in Appendix 1 to 12 .

The first sedimentary unit was interpreted as recent in age with tens centimeter of thickness from the bottom sea bed surface down to a certain depth. In few locations the thickness is more than $1.5 \mathrm{~m}$. The sediment was characterized by its softness or low density and the abundance of shells which dominate the sediment fragments.

The shell abundance was generally more than $30 \%$ to even until $90 \%$. This shallow sediment was generally grayish green in color and grain size variation from clay to coarse sand. The grain size variation indicates variation of weak to strong deposition energy system. This depositional energy system is still working at present, which is reflected in poorly sorted sedimentation where the grain sizes mix randomly.

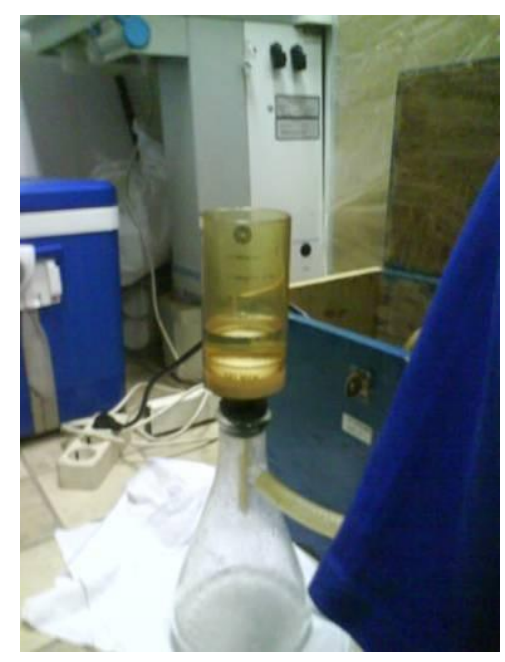

Figure 5. Filtering $250 \mathrm{ml}$ water sample using 20 micron filter paper 


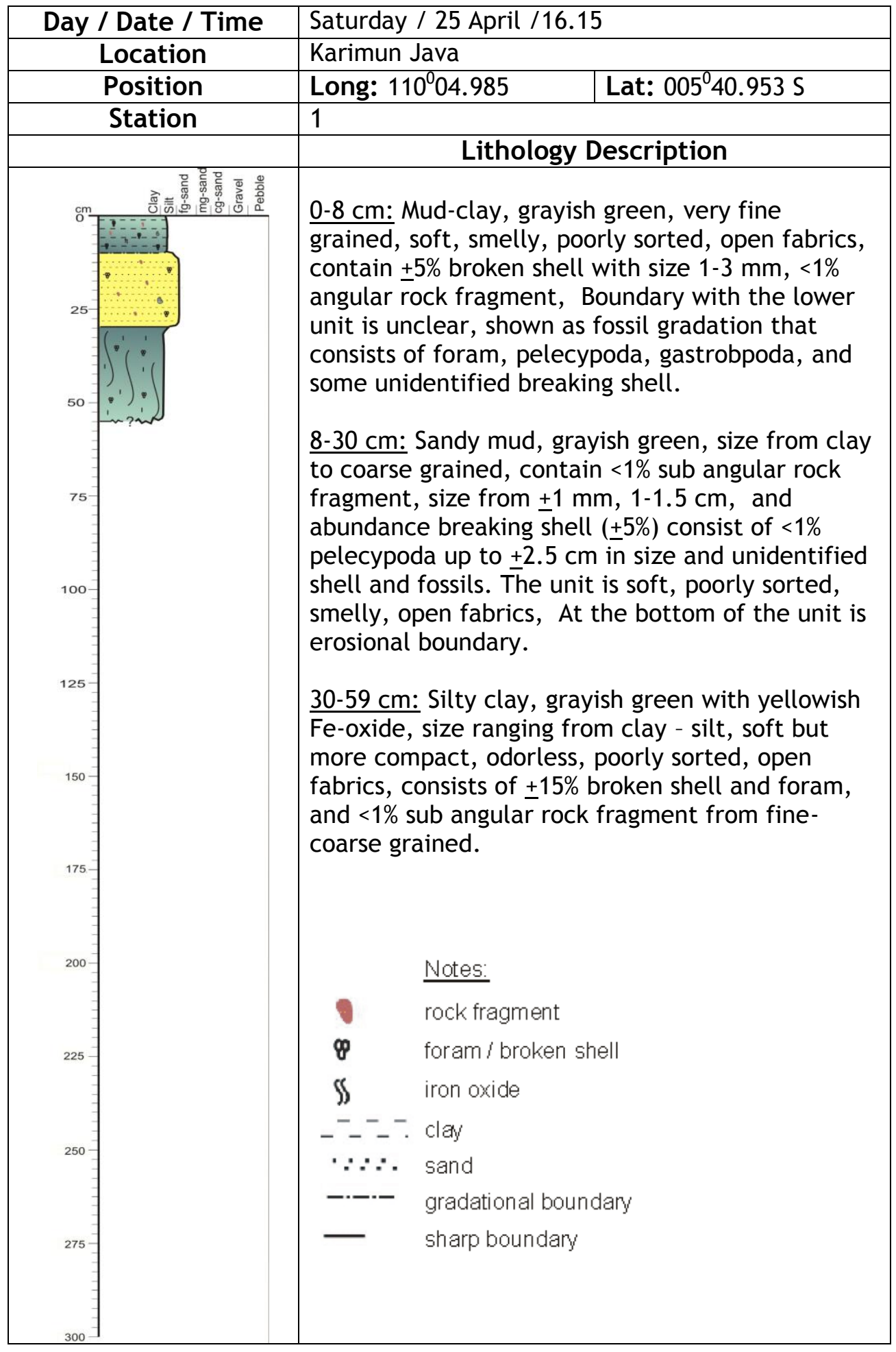

Figure 6. Stratigraphic profile at station ST.1

The second sedimentary unit was indicated by sharp contact with the above, shallower, first sedimentary unit. The main characteristic of this sediment is its higher density resembling the density of rock, but less compacted and the hardness level is still low, hence can be broken easily by hand. The unit, 
generally, is brownish in color, sometimes thin carbon lenses or remnant of decomposed vegetation was found. The abundance of shell or fossil is usually less than $5 \%$. The sediment is possibly Pleistocene in age; however an accurate age determination would still be needed for further confirmation.

\subsection{Distribution of Recent Sediment and Paleosoil Depth}

Two maps were generated as a result of Karimun Java Sea field work: paleosoil depth and recent sediment thickness maps (Figure 7 and 8).
Paleosoil depth map (Figure 7) was generated by adding total depth from water surface with the thickness of recent sediment, which is determined from core identification. On the other hand the recent sediment thickness was measured from seabed floor surface down to a depth where paleosoil is encountered, or where sediment characteristic changes occurs from soft-low density (first stratigraphic unit) to higher density- less compacted-low hardness (second stratigraphic unit). Table 1 shows the relationship between paleosoil depth and recent sediment thickness.

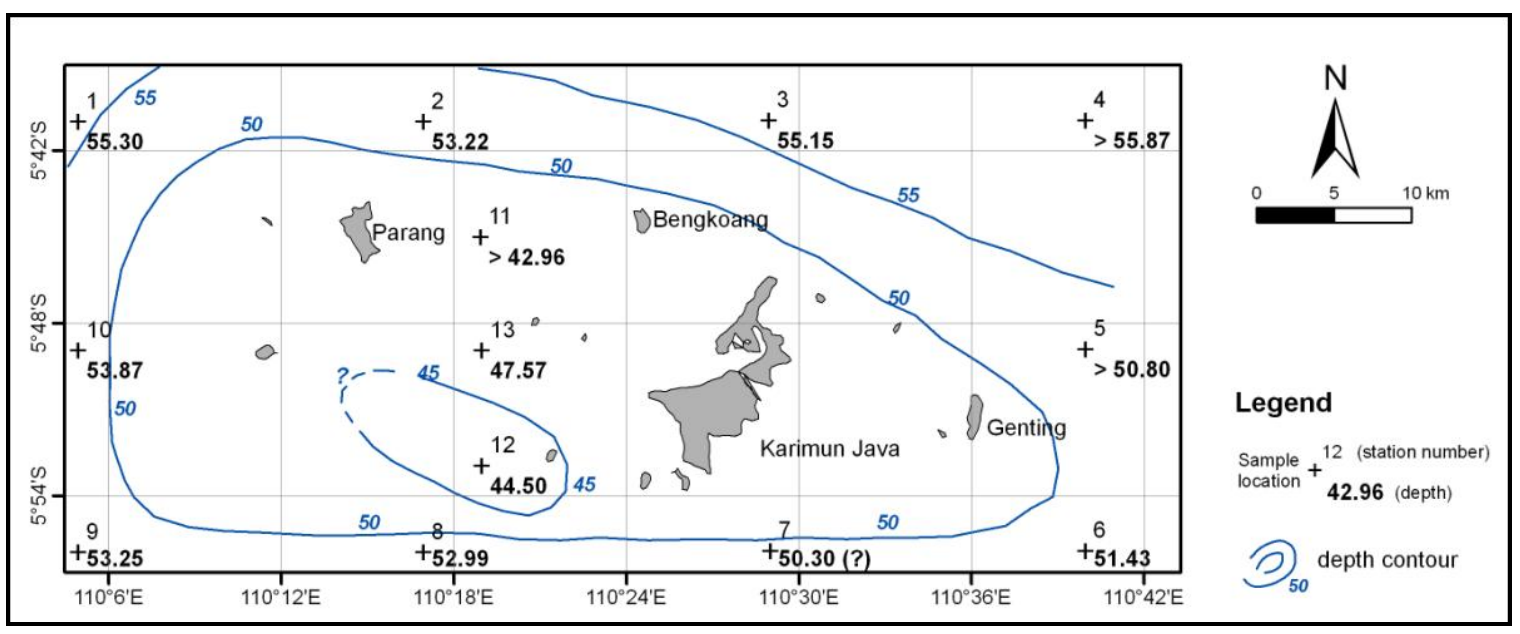

Figure 7. Paleosoil surface depth distribution

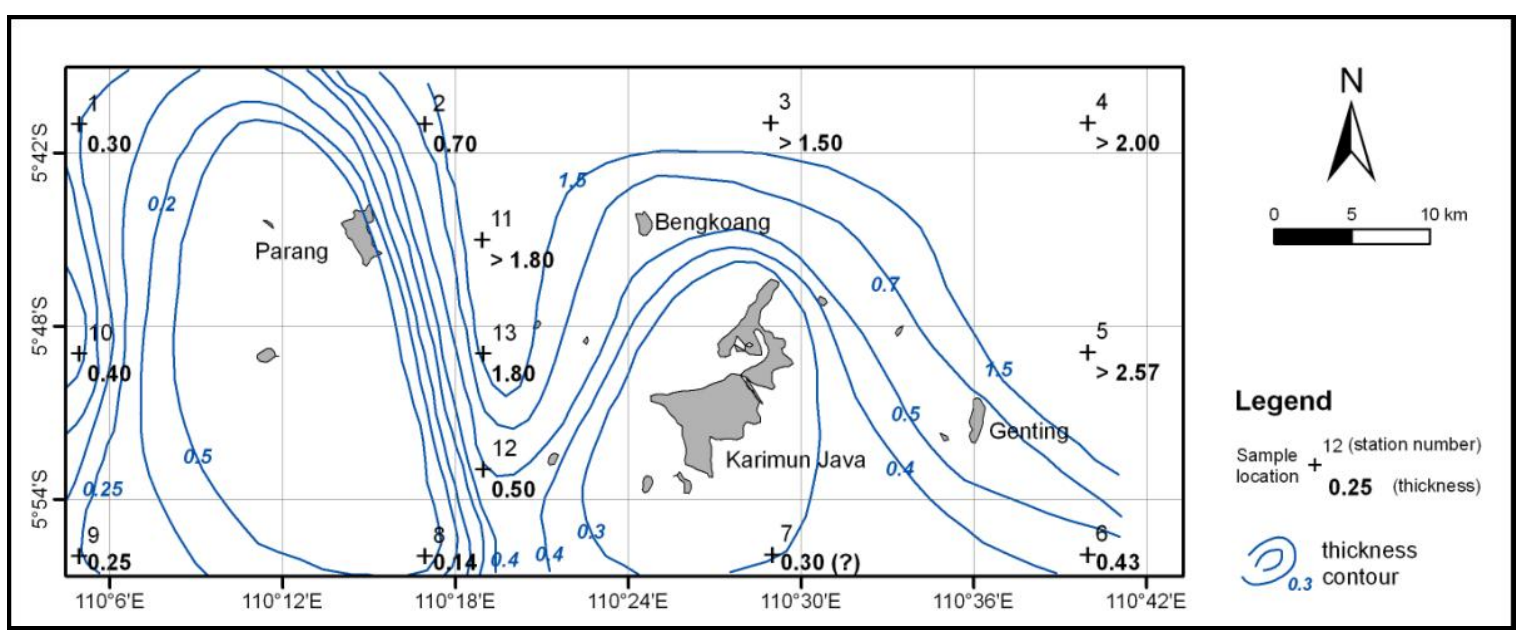

Figure 8. Recent sediment thickness (isochor) distribution 
Table 1. Paleosoil depth

\begin{tabular}{cccc}
\hline $\begin{array}{c}\text { Sample } \\
\text { No. }\end{array}$ & $\begin{array}{c}\text { Water } \\
\text { depth }(\mathbf{m})\end{array}$ & $\begin{array}{c}\text { Paleosoil } \\
\text { depth }(\mathbf{m})\end{array}$ & $\begin{array}{c}\text { Recent sediment } \\
\text { thickness }(\mathbf{m})\end{array}$ \\
\hline ST-01 & 55 & 55.3 & 0.3 \\
ST-02 & 52.57 & 53.27 & 0.7 \\
ST-03 & 53.65 & $>55.15$ & $>1.50$ \\
ST-04 & 53.87 & $>55.87$ & $>2.00$ \\
ST-05 & 48.23 & $>50.80$ & $>2.57$ \\
ST-06 & 51 & 51.43 & 0.43 \\
ST-07 & 50 & $\geq 50.30$ & $\geq 0.30$ \\
ST-08 & 52.85 & 52.99 & 0.14 \\
ST-09 & 53 & 53.25 & 0.25 \\
ST-10 & 53.47 & 53.87 & 0.4 \\
ST-11 & 41.16 & $>42.96$ & $>1.80$ \\
ST-12 & 44 & 44.5 & 0.5 \\
ST-13 & 45.77 & 47.57 & 1.8 \\
\hline
\end{tabular}

\subsection{Discussion on Recent Sediment Distribution}

Based on stratigraphic profile at every core sample, erosional boundaries between paleosoil and recent sediment are observed. This evidence shows that at one time, sedimentation process and supply into Karimun Java Sea was stopped. The previous deposited sediment became more massive and at several places peat was formed. After this period a very significant amount of sediment supply was deposited and eroded the previous almost dense and hard sediment. The last sedimentation process is continued until today, forming the recent sediment, while the previous one became the paleosoil. When this research is conducted, it was not known when and why the sediment supply stopped. There are several possibilities to explain the phenomena. Sea level rise may create an almost still current at the bottom of the sea and only suspension soluble sediment like clay can be deposited. Another possibility is there was simply no erosion and hence no sediment supply from the surrounding islands. Those possibilities needs to be tested since it will help to understand the sudden climate changes that has happened and may also happen in the future that could disturb the ecosystem of Karimun Java Sea and its surrounding area.

Generally, based on paleosoil surface (Figure 7), at the time of recent sediment deposition process, the sea depth are uniform, relatively gentle slope, and sediment materials were deposited at $50-55 \mathrm{~cm}$ below present sea floor, except at sample ST-12 location which is slightly shallower, at around $45 \mathrm{~cm}$. The paleosoil would give a pattern of basin layout for the next deposited recent sediment. Assuming there were no disturbance and the sedimentation process worked uniformly throughout the sampling area, the recent sediment pattern distribution would be similar to paleosoil distribution. However that is not the case, as shown in Figure 8. Sediment pattern was distributed into two poles, one is located around Karimun Besar Island in the east, and the other is located in the west part, around Parang Island. The two poles met in the middle area of 
study, at sample location ST-2, ST-11, ST-12, ST-13, and ST-8. Thus, it does not suggest a uniform sedimentation process throughout the research area, resulting recent sediment spatial distribution.

Two hypotheses can be proposed to answer the cause of un-uniformity of the deposition process: (1) there is a NorthSouth geological structure around ST-2, ST-11, ST-12, ST-13, and ST-8 sample locations, (2) the amount of samples acquired does not present the true recent sediment distribution, hence resulting two poles pattern. Further studies are required to examine those two hypotheses; geological structure identification and more representative amount of sample points throughout research area.
Apart from any of the above reasons, it is clear that the main sediment source were originated from main islands such as Parang and Karimun Besar in Karimun Java Sea area. Sediment thickness pattern also support this conclusion, where recent sediment thickness near the islands are relatively thinner than the one in the farther area, as the cause of sorting process by marine wave.

\subsection{Granulometry Analysis Discussion}

Grain size analysis results are summarized in distribution curve of Figure 9 and 10. Those curves are then compared to Bassilie and Tanner's (1995) grain size versus marine current curve (Figure 11).

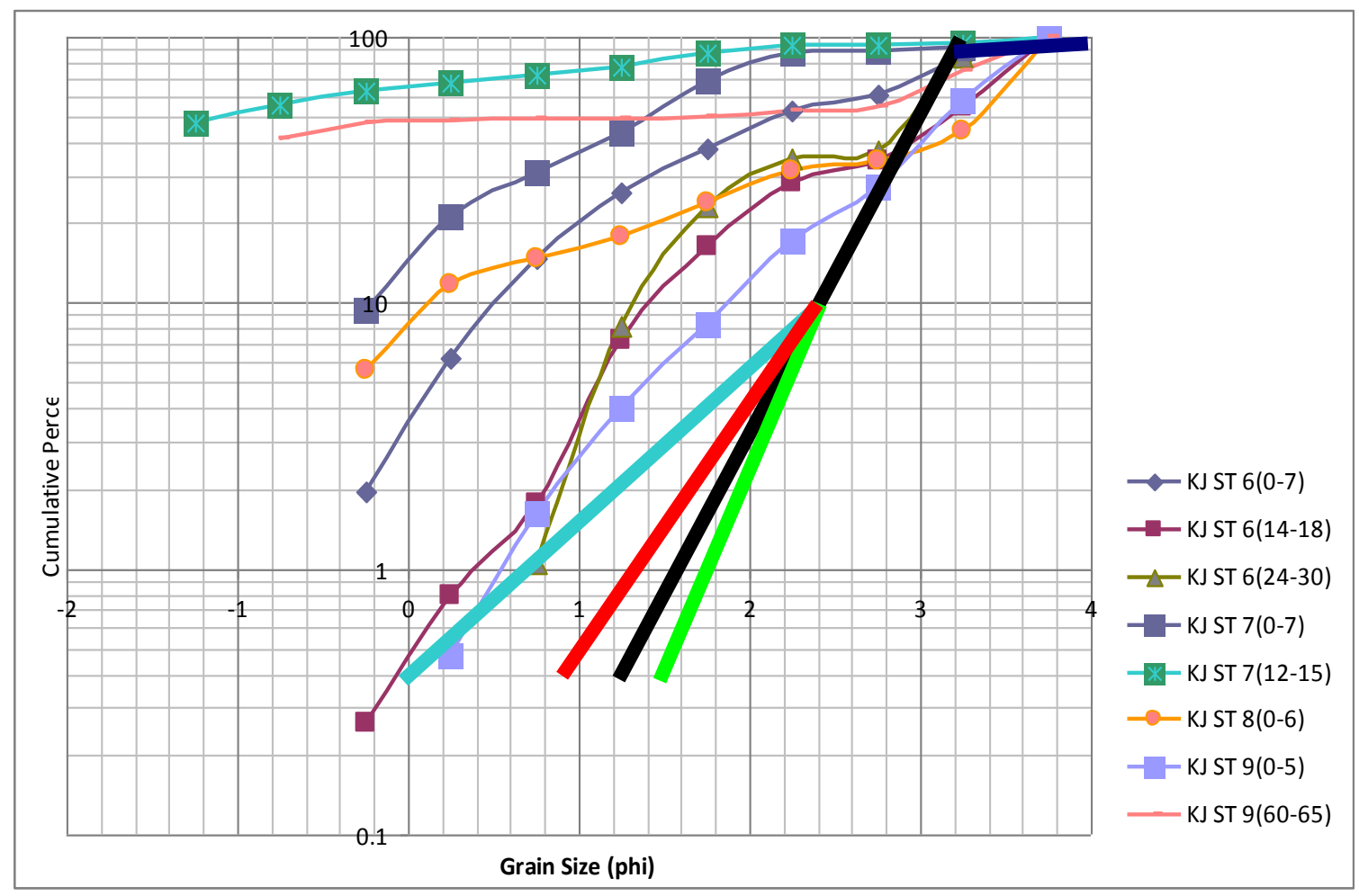

Figure 9. Grain size distribution curve of ST-6 to ST-9 


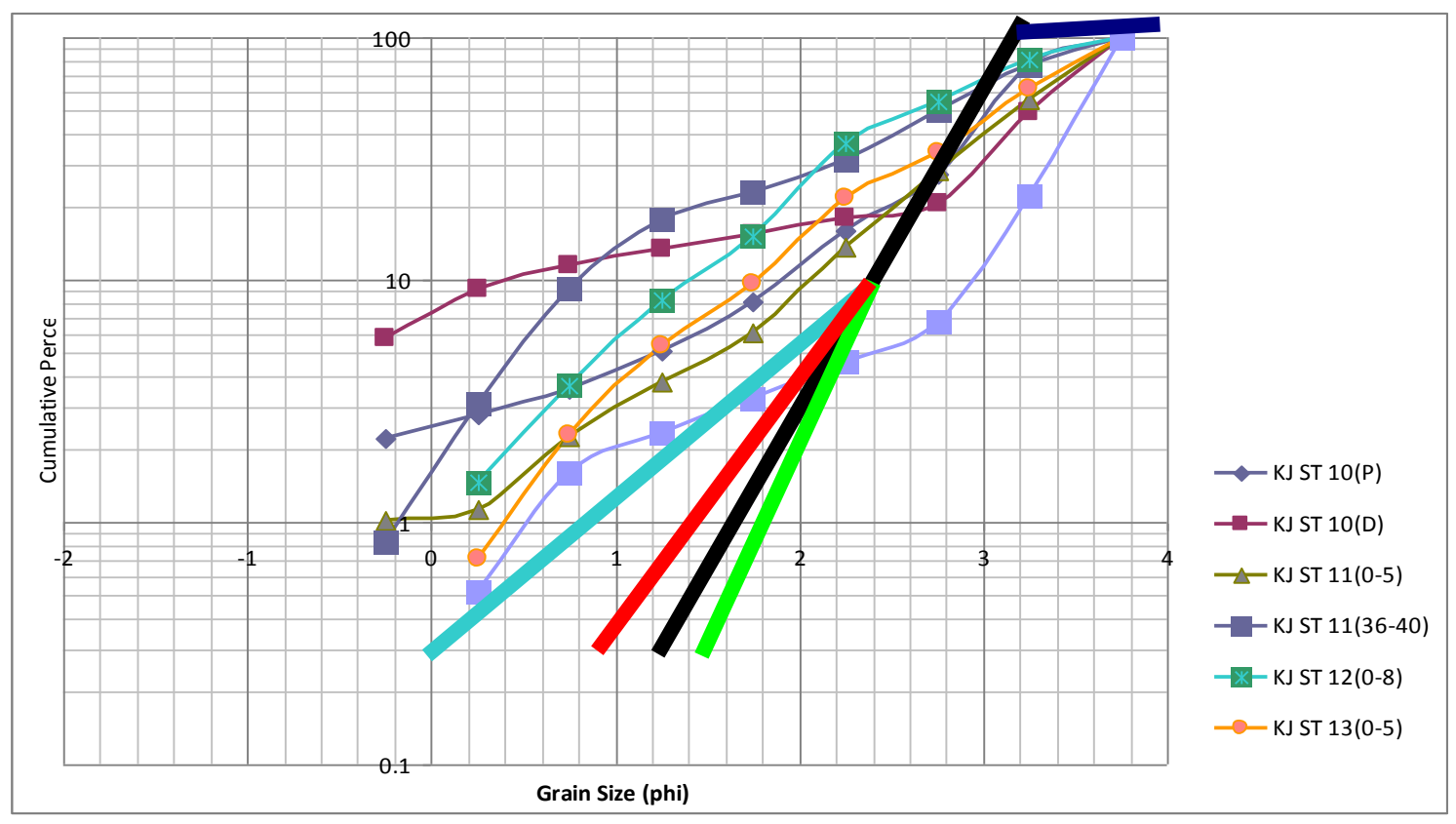

Figure 10. Grain size distribution curve of ST-10 to ST-13

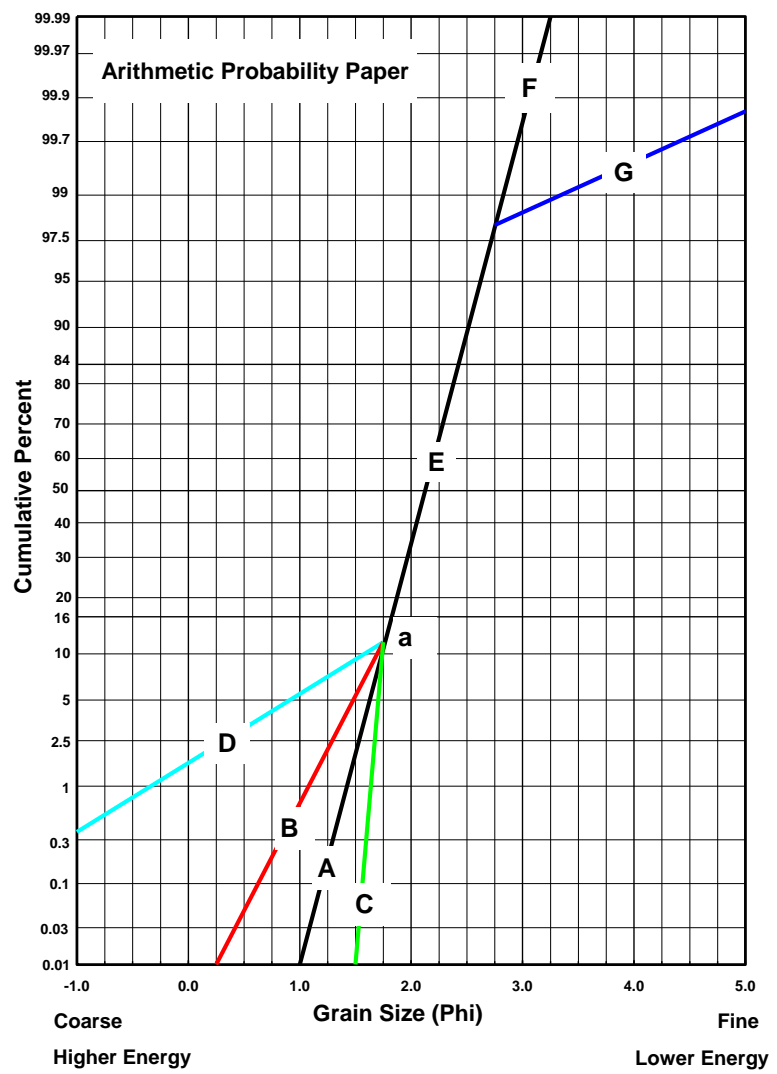

\begin{tabular}{|c|c|}
\hline SEGMENT & $\begin{array}{c}\text { DESCRIPTION OF } \\
\text { GRANULOMETRIC INTERPRETATION }\end{array}$ \\
\hline AEF & $\begin{array}{l}\text { The Gaussian distribution. Plots as a straight } \\
\text { line on probability paper. }\end{array}$ \\
\hline B & $\begin{array}{l}\text { Indicates that the operating transpo-depositional } \\
\text { force element is wave activity; point a relative to } \\
\text { segment } E \text { is termed the surf break. This slope } \\
\text { which is relatively gentle, represents beach sand. } \\
\text { The higher the slope of segment B, the higher the } \\
\text { wave energy. Note that for sand-sized material, } \\
\text { the surf break normally appears for low- to mod- } \\
\text { erate-wave energy conditions. For high-energy } \\
\text { waves, point a moves off the plot (toward the bot- } \\
\text { tom) and segment B disappers (i.e., the wave } \\
\text { energy is over-powering even to the coarsest } \\
\text { sand available (Savage, 1958; Balsillie, 1999). }\end{array}$ \\
\hline C & $\begin{array}{l}\text { Indicates eolian processes; point a is termed, } \\
\text { relative to segment B, the eolian hump. }\end{array}$ \\
\hline D & $\begin{array}{l}\text { Represents fluvial energy; has a steep slope. The } \\
\text { greater the slope the higher the energy level. This } \\
\text { segment is termed the fluvial coarse tail. It may } \\
\text { also represent transpo-depositional tidal current } \\
\text { processes. }\end{array}$ \\
\hline $\mathbf{E}$ & Central segment of the sample distribution. \\
\hline G & $\begin{array}{l}\text { Represents the low energy tail termed the setting } \\
\text { tail and, if present, may indicate lowering of } \\
\text { energy for the total distribution or for distribution } \\
\text { segments containing coarser sediment. It signi- } \\
\text { fies settling from water. }\end{array}$ \\
\hline
\end{tabular}

NOTE: This tool should assessed using multiple samples (i.e., sample suites) collected along a bedding plane.

Figure 11.Grain size distribution curve and sea current analysis (Bassilie dan Tanner, 1995) 
Grain size comparison of sediment samples in Karimun Java Sea shows more than $50 \%$ of sediment was deposited in low energy sea wave environment, which is characterized by the abundance of grain size above 3 phi. This characteristic indicate that Karimun Java Sea was generally calm/quiet, there were no high energy sea wave nor extreme wave and sudden climate changes. Those are ideal environment for the growth of coral reef and its complementary biotas. To confirm this statement, related plankton and microbiology data needs to be studied and examined.

\subsection{TSS Analysis Discussion}

The TSS analysis result is shown in Table 2. The values of TSS are acquired at sea surface $(0-0.30 \mathrm{~m})$ and bottom (at depth shown in the table 2).

At sea surface, TSS distribution shows value between 0.018 and 0.034 $\mathrm{gr} / 1$, with average of $0.025 \mathrm{gr} / \mathrm{l}$. The TSS surface spatial distribution is shown in Figure 12. All TSS sample values are very low compared to the threshold value defined by Ministry of Environment (KLH), which is $0.70 \mathrm{gr} / 1$ (Kepmen, 1988). The result indicates that Karimun Java Sea is a clean and good marine environment for marine biota, especially coral reef growth.

Table 2. Total Suspended Solid analysis result from Karimun Java Sea in 2009

\begin{tabular}{|c|c|c|c|c|c|}
\hline \multirow{2}{*}{$\begin{array}{l}\text { Station } \\
\text { No. }\end{array}$} & \multicolumn{2}{|c|}{ Position } & \multirow{2}{*}{\multicolumn{2}{|c|}{$\begin{array}{l}\text { Sea depth Sample depth } \\
\begin{array}{ll}(\mathrm{m}) & (\mathrm{m})\end{array}\end{array}$}} & \multirow{2}{*}{$\begin{array}{c}\text { TSS } \\
\text { (gr/ltr) }\end{array}$} \\
\hline & Lattitude (S) & Longitude (E) & & & \\
\hline \multirow[t]{2}{*}{1} & 5.68 & 110.08 & 55 & 0 & 0.028 \\
\hline & & & & 50 & 0.027 \\
\hline \multirow[t]{2}{*}{2} & 5.68 & 110.28 & 52 & 0 & 0.026 \\
\hline & & & & 50 & 0.026 \\
\hline \multirow[t]{2}{*}{3} & 5.68 & 110.48 & 53 & 0 & 0.022 \\
\hline & & & & 50 & 0.026 \\
\hline \multirow[t]{2}{*}{4} & 5.68 & 110.67 & 53 & 0 & 0.018 \\
\hline & & & & 50 & 0.024 \\
\hline \multirow[t]{2}{*}{5} & 5.82 & 110.67 & 48 & 0 & 0.034 \\
\hline & & & & 45 & 0.030 \\
\hline \multirow[t]{2}{*}{6} & 5.93 & 110.67 & 51 & 0 & 0.032 \\
\hline & & & & 48 & 0.026 \\
\hline \multirow[t]{2}{*}{7} & 5.93 & 110.48 & 50 & 0 & 0.024 \\
\hline & & & & 45 & 0.026 \\
\hline \multirow[t]{2}{*}{8} & 5.93 & 110.28 & 52 & 0 & 0.023 \\
\hline & & & & 48 & 0.026 \\
\hline \multirow[t]{2}{*}{9} & 5.93 & 110.08 & 53 & 0 & 0.030 \\
\hline & & & & 49 & 0.030 \\
\hline \multirow[t]{2}{*}{10} & 5.82 & 110.08 & 53 & 0 & 0.024 \\
\hline & & & & 50 & 0.025 \\
\hline \multirow[t]{2}{*}{11} & 5.75 & 110.32 & 41 & 0 & 0.024 \\
\hline & & & & 39 & 0.026 \\
\hline \multirow[t]{2}{*}{12} & 5.88 & 110.32 & 44 & 0 & 0.022 \\
\hline & & & & 40 & 0.030 \\
\hline \multirow[t]{2}{*}{13} & 5.82 & 110.32 & 45 & 0 & 0.026 \\
\hline & & & & 40 & 0.027 \\
\hline
\end{tabular}




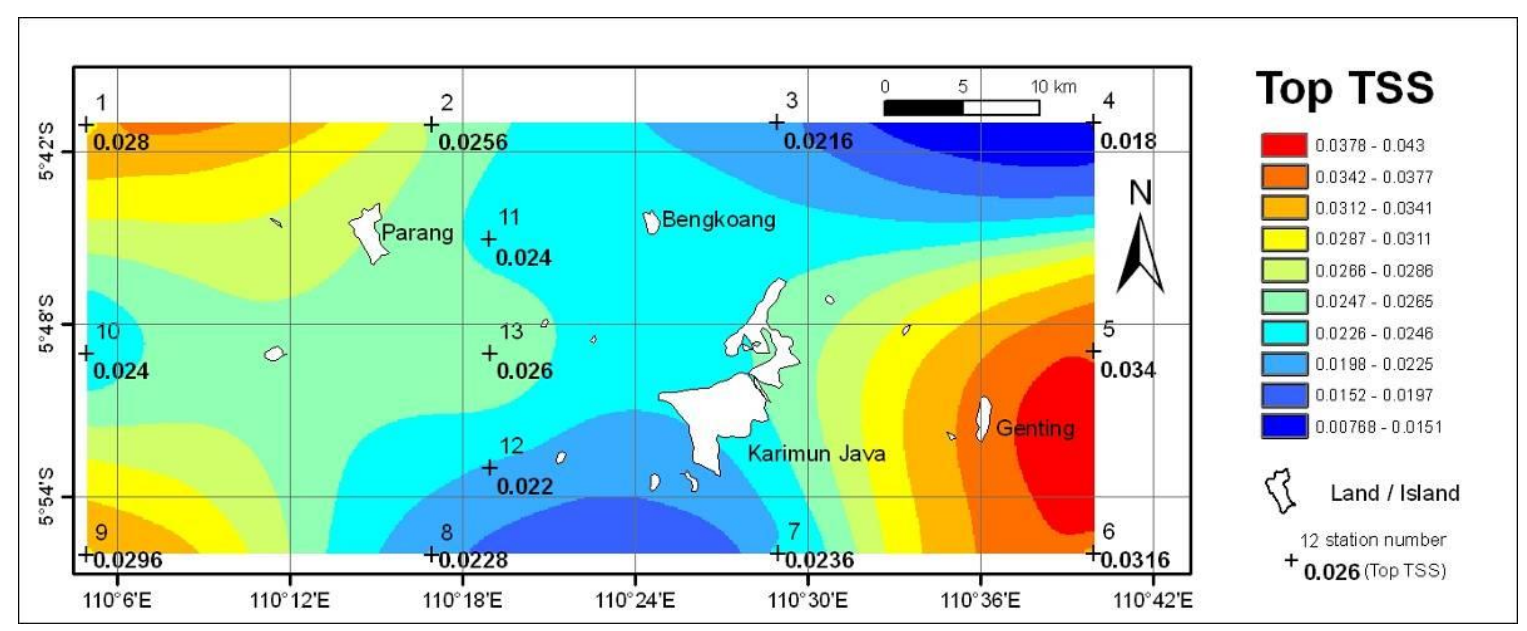

Figure 12. Top TSS (gr/l) surface distribution

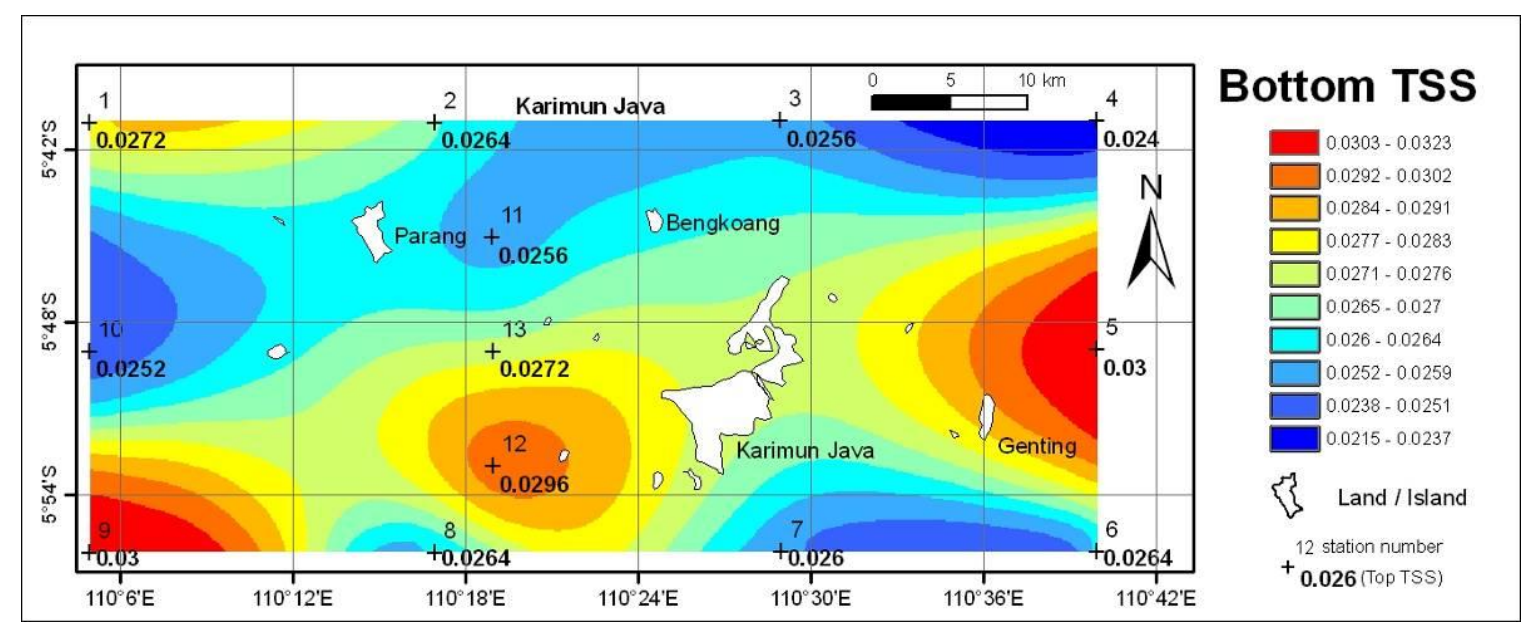

Figure 13. Bottom TSS (gr/l) surface distribution

At bottom sea, TSS distribution shows value between 0.024 and 0.030 $\mathrm{gr} / \mathrm{l}$, with average value of $0.027 \mathrm{gr} / \mathrm{l}$. Bottom TSS surface spatial distribution is shown in Figure 13. Although bottom TSS values are generally slightly higher than top TSS values, they are still very low compared to $0.70 \mathrm{gr} / \mathrm{l}$ threshold value of KLH. It also indicates a clean and good marine environment for coral reef growth.

\section{CONCLUSION}

Based on sediment thickness analysis and stratigraphic profile, sediment source in Karimun Java Sea was originated from the surrounding main islands i.e., Parang and Karimun Besar. Based on grain size analysis, 50\% of sediment in the area was deposited at low energy sea wave environment. This indicated that Karimun Java Sea was generally calm/quiet sea. Therefore, there were not high sea wave energy nor extreme wave or sudden climate changes.

The TSS distribution at the sea water surface and near sea bed showed very low value, compared to $0.70 \mathrm{gr} / \mathrm{l}$ threshold value defined by KLH, which indicates a clean marine environment. These results indicated that Karimun Java Sea is an ideal environment for coral reef growth of and its complementary biotas. 


\section{ACKNOWLEDGEMENT}

This publication is a result of sedimentology survey conducted during "Pelayaran Kebangsaan" research activities program (24 April - 2 May 2009) supported by DIKTI and P20 LIPI. We acknowledge the captain and crews of Baruna Jaya VIII research marine vessel for their assistance during sample acquisition. This paper is finalized and completed with the assistance of Hendro Wibowo M.Sc, a Lecture Assistant in Geology Study Program of ITB.

\section{REFERENCES}

Acevedo, R. and J. Morelock. 1988. Effects of terrigenous influx on coral reefzonation in southwestern Puerto Rico. Proc. 6th Inter. Coral Reef Symp., 2:189-193.

Balsillie, J.H. 1995. William F. Tanner on Environmental Clastic Granulometry: Florida Geological Survey, Special Pubication No.40, 144 p.

Cortes, J. 1990. The coral reefs of Golfo Dulce, Costa Rica: distribution and community structure. Atoll Res. Bull., 344:1-38.

Dodge, R. E., R. C. Aller and J. Thomson. 1974. Coral growth related to resuspension of bottom sediments. Nature, 247:574-577.

Hubbard, J. A. E. B. and Y. P. Pocock. 1972. Sediment rejection by recent scleractinian corals: a key to paleoenvironmental rcconstruction. Geologische Rundsehau, 61:598626.
Hubbard, D. K., J. D. Stumb and B. Carter. 1987. Sedimentation and reef development in Hawknest, Fish and Reef Bays, St. John, U.S. Virgin Islands. Biosphere Reserve Research Report, 21:199.

Hsieh, H. 1995. Spatial and temporal patterns of polychaete communities in a subtropical mangrove swamp: influences of sediment and microhabitat, Mar Ecol Prog Ser., 127:157-167.

Lillesand, T. and R. Kiefer. 1994. Remote Sensing and Image Interpretation. John Wiley and Sons, Inc., New York, 468p.

Menteri Negara KLH. 1988. Keputusan Menteri Negara Kependudukan dan Lingkungan Hidup No. Kep. 02/Men KLH/1988 tentang pedoman baku mutu lingkungan . Sekretariat Menteri Negara Kependudukan dan Lingkungan Hidup Jakarta.

Rice A. Stanley and Hunter L. Cynthia, 1992, Effects of Suspended Sediment and Burial on Scleratinian Corals from West Central Florida Patch Reef. Bulletin of Marine Science, S1(3):429-442.

Rogers, C.S. 1990. Responses of coral reefs and reef organisms to sedimentation. Marine Ecology Progress Series, 62: 185-202

Rogers, C. S., 1983. Sublethal and lethal effects of sediments applied to common Caribbean reef corals in the field. Mar. Pollut. Bull., 14:378-382.

Roy, K. J. and S. V. Smith. 1971. Sedimentation and coral reef development in turbid water: Fanning Lagoon. Pacific Sci., 25: 234-248. 


\section{APPENDIX 1. Stratigraphic Colums}

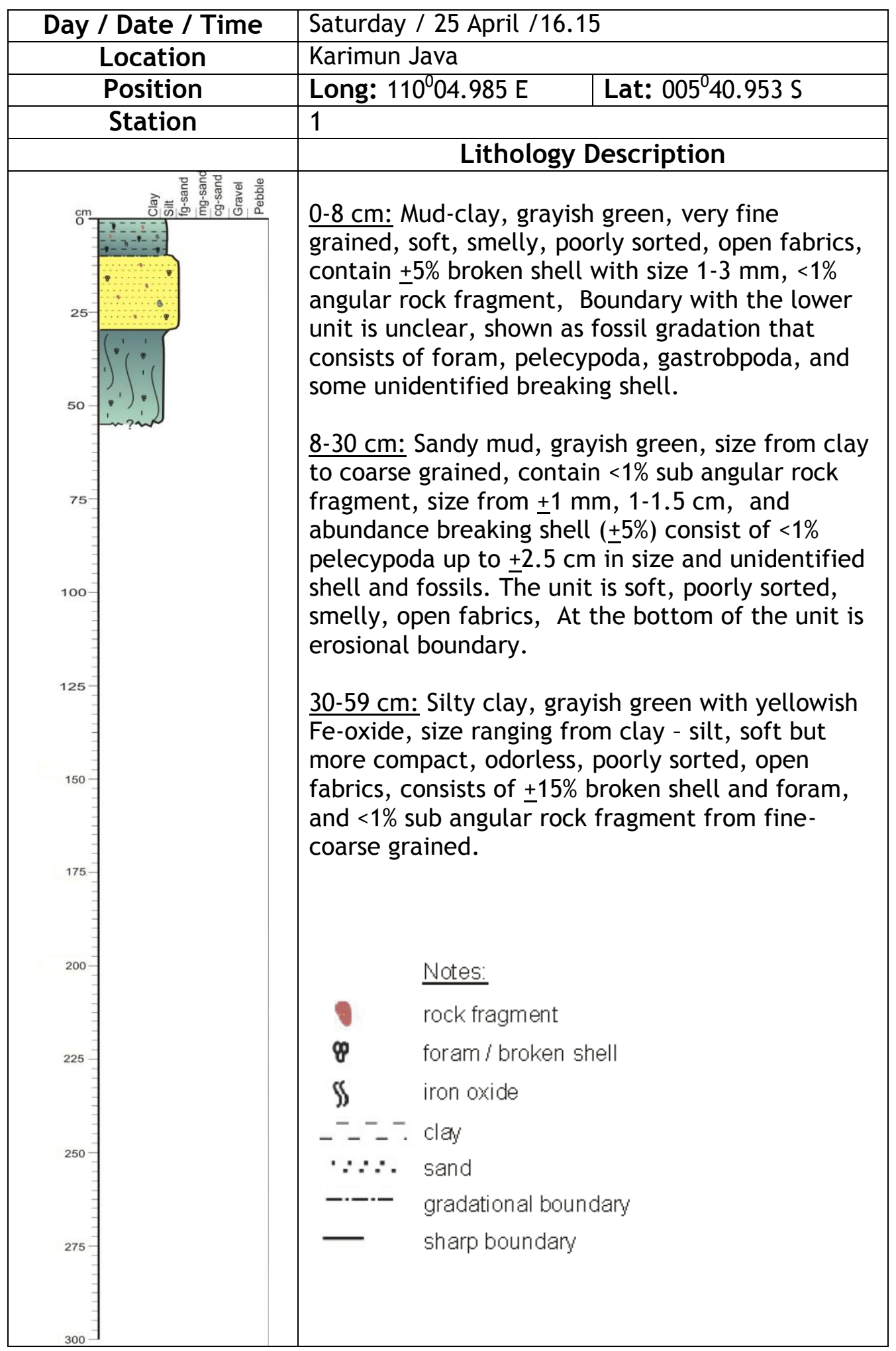




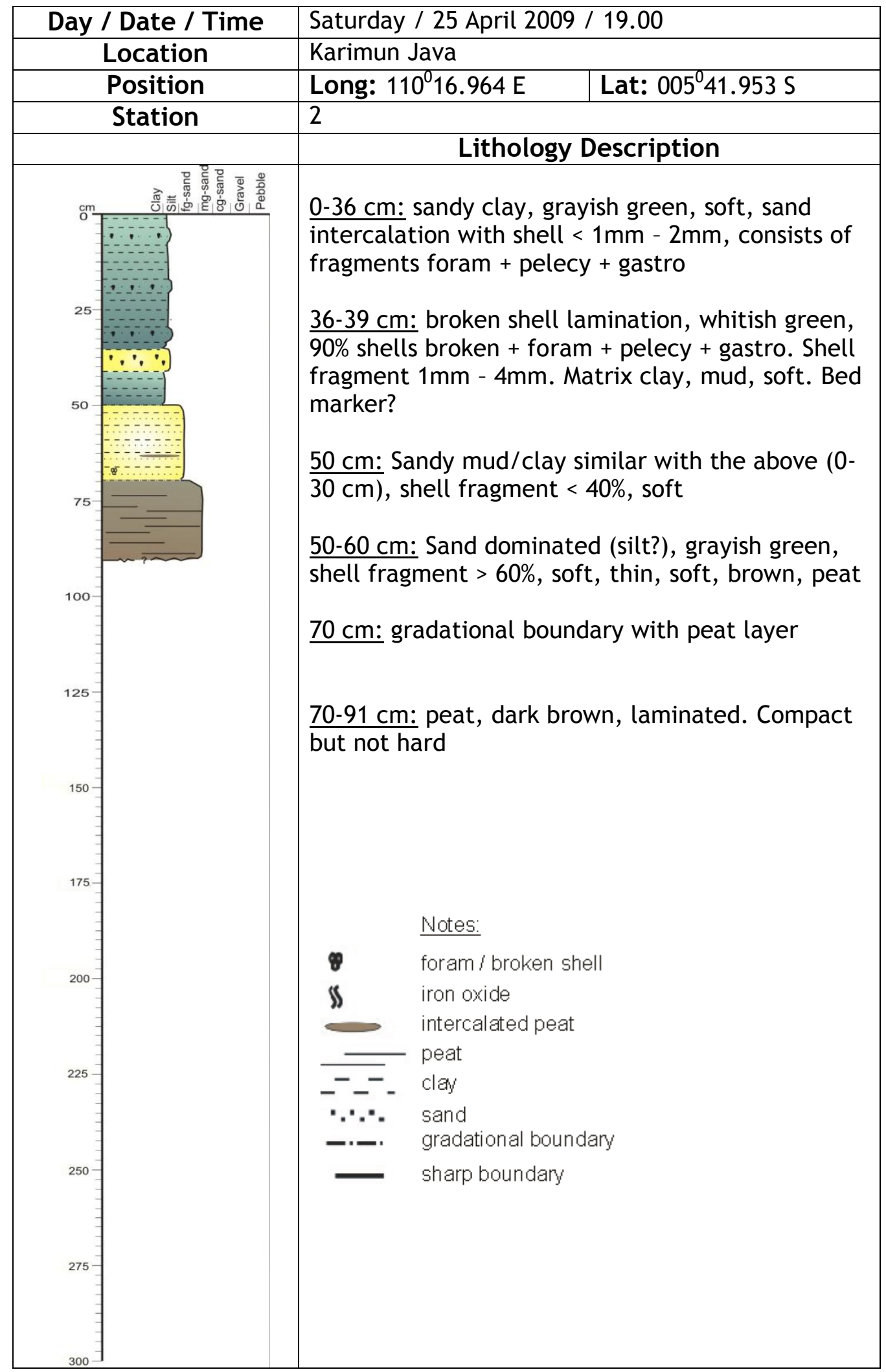




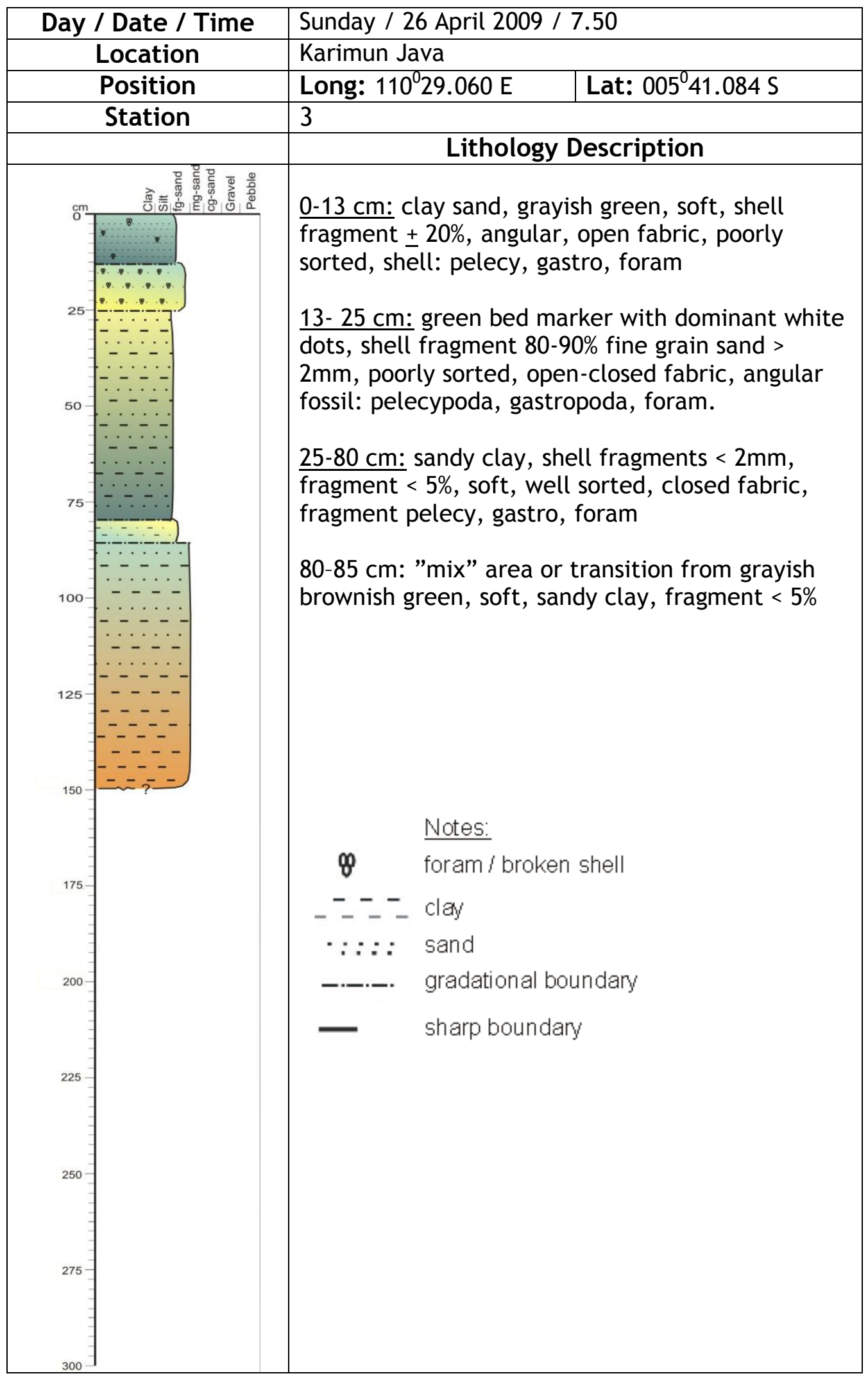




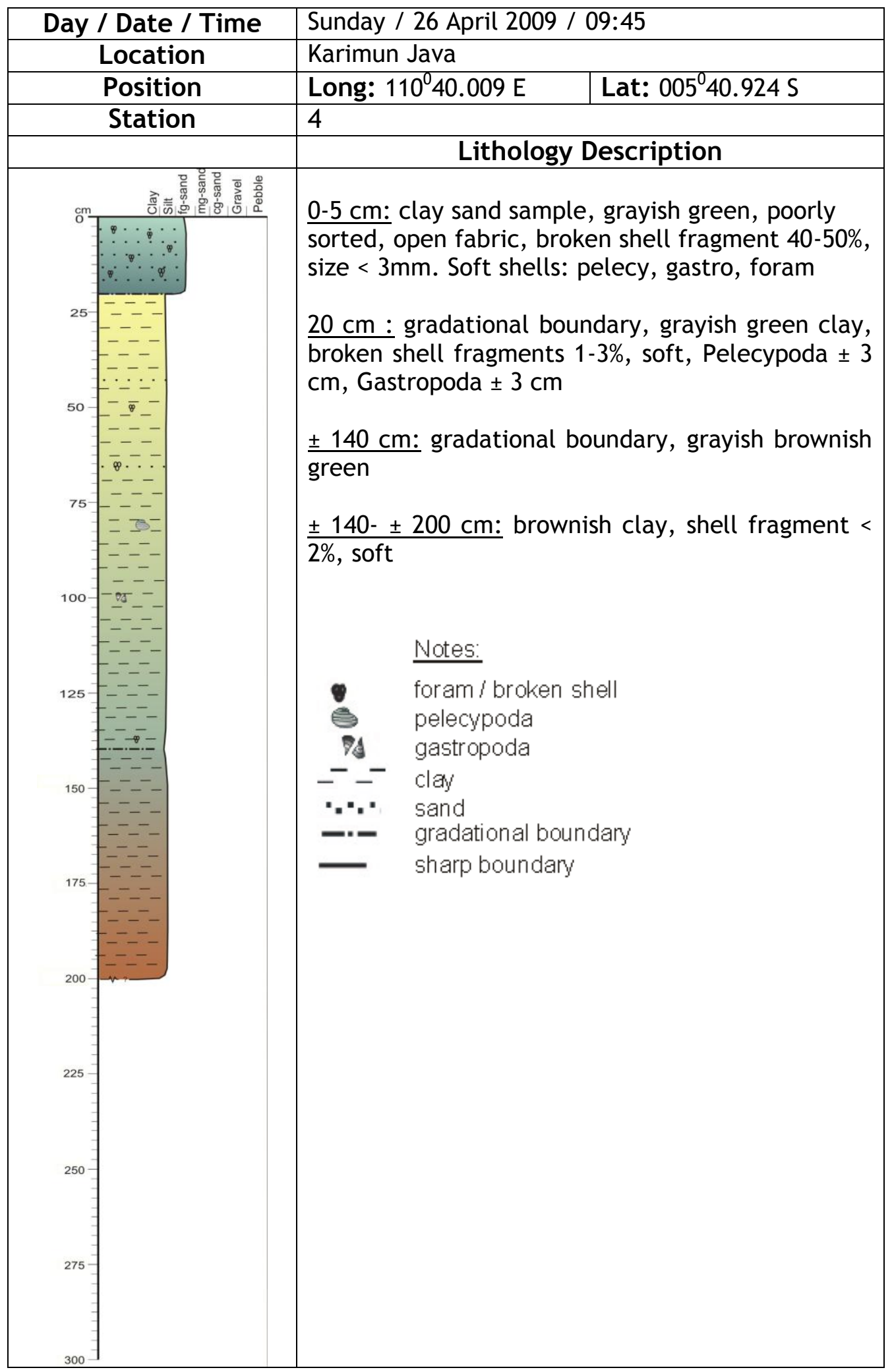




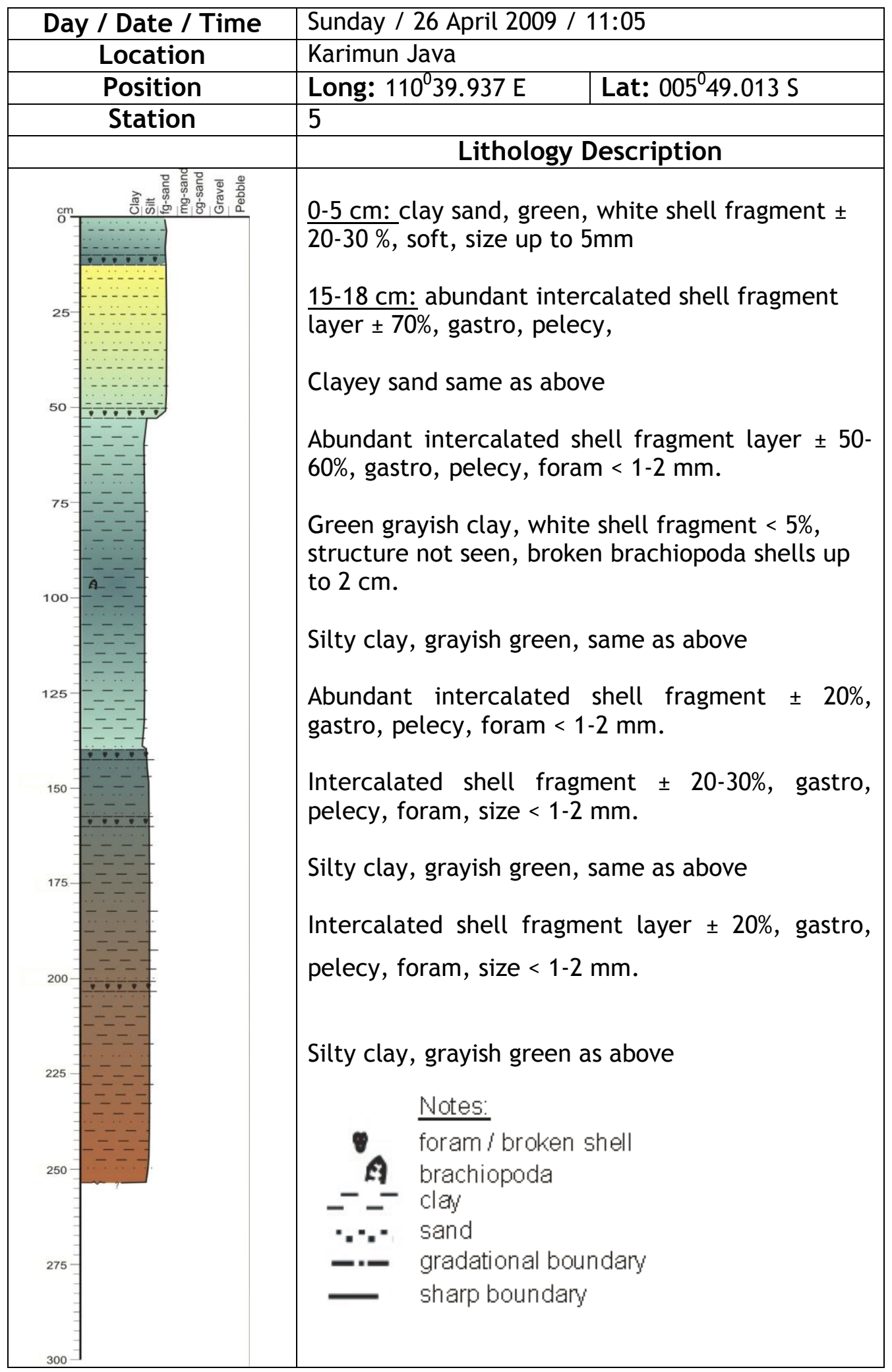




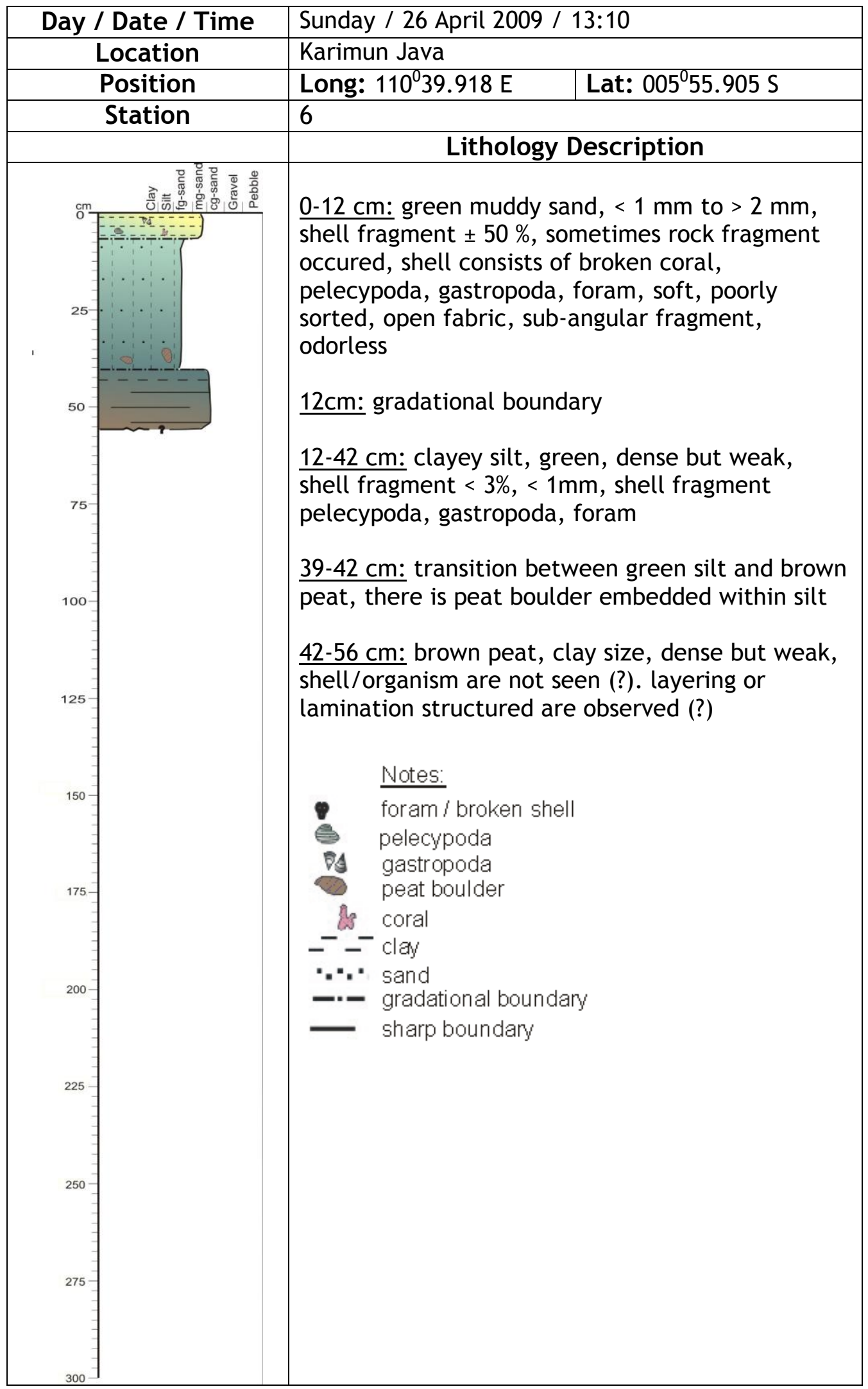




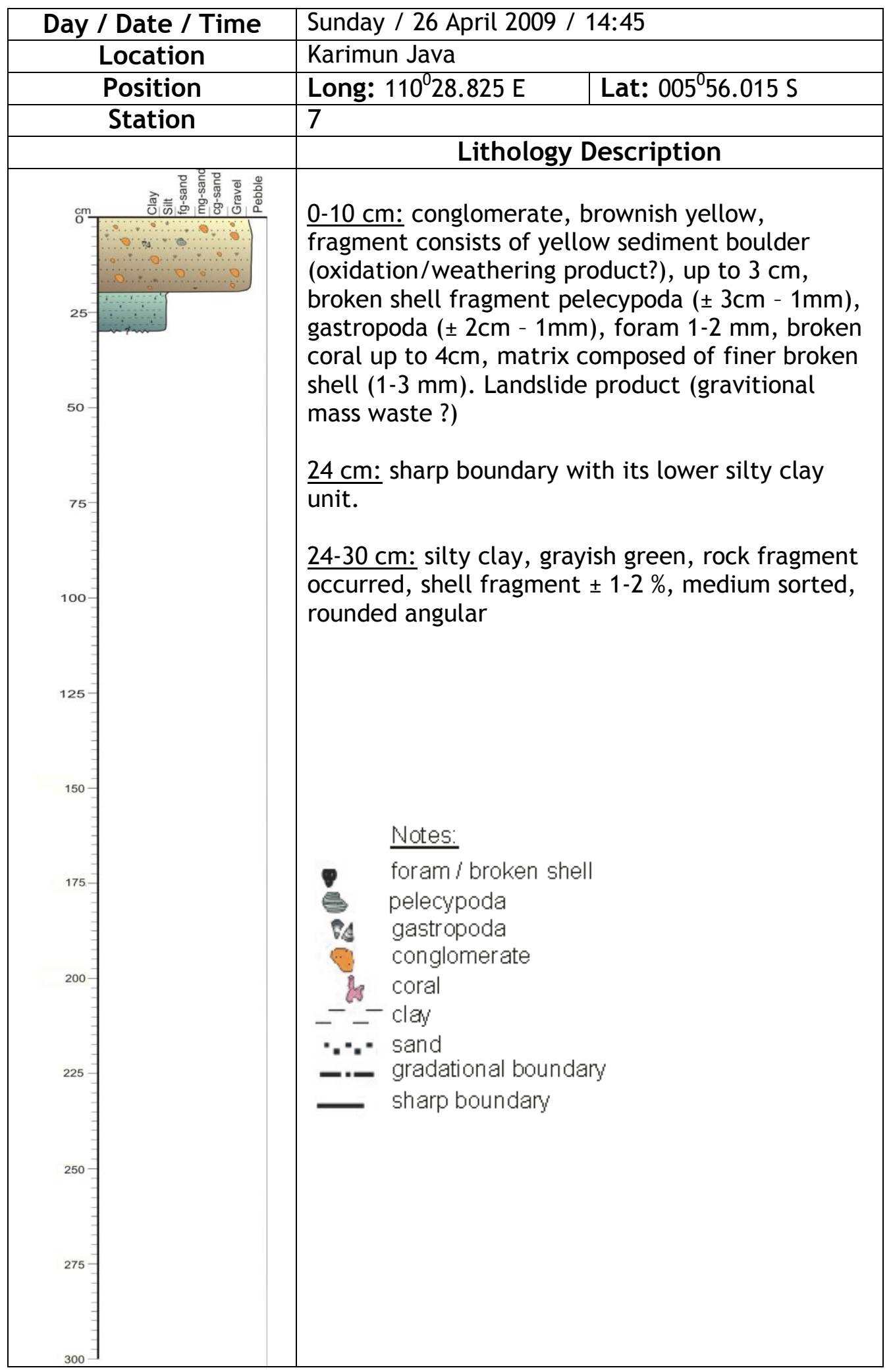




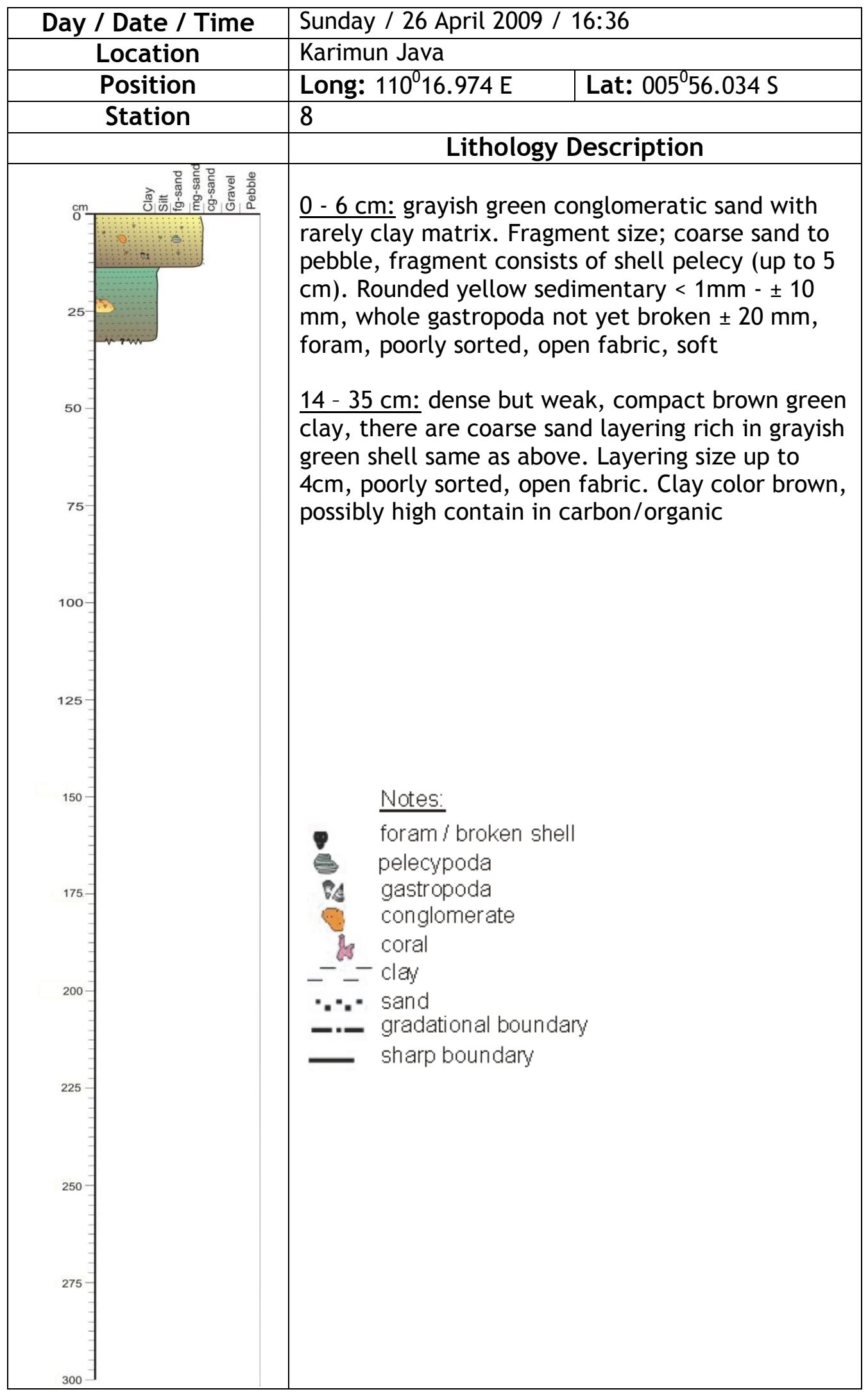




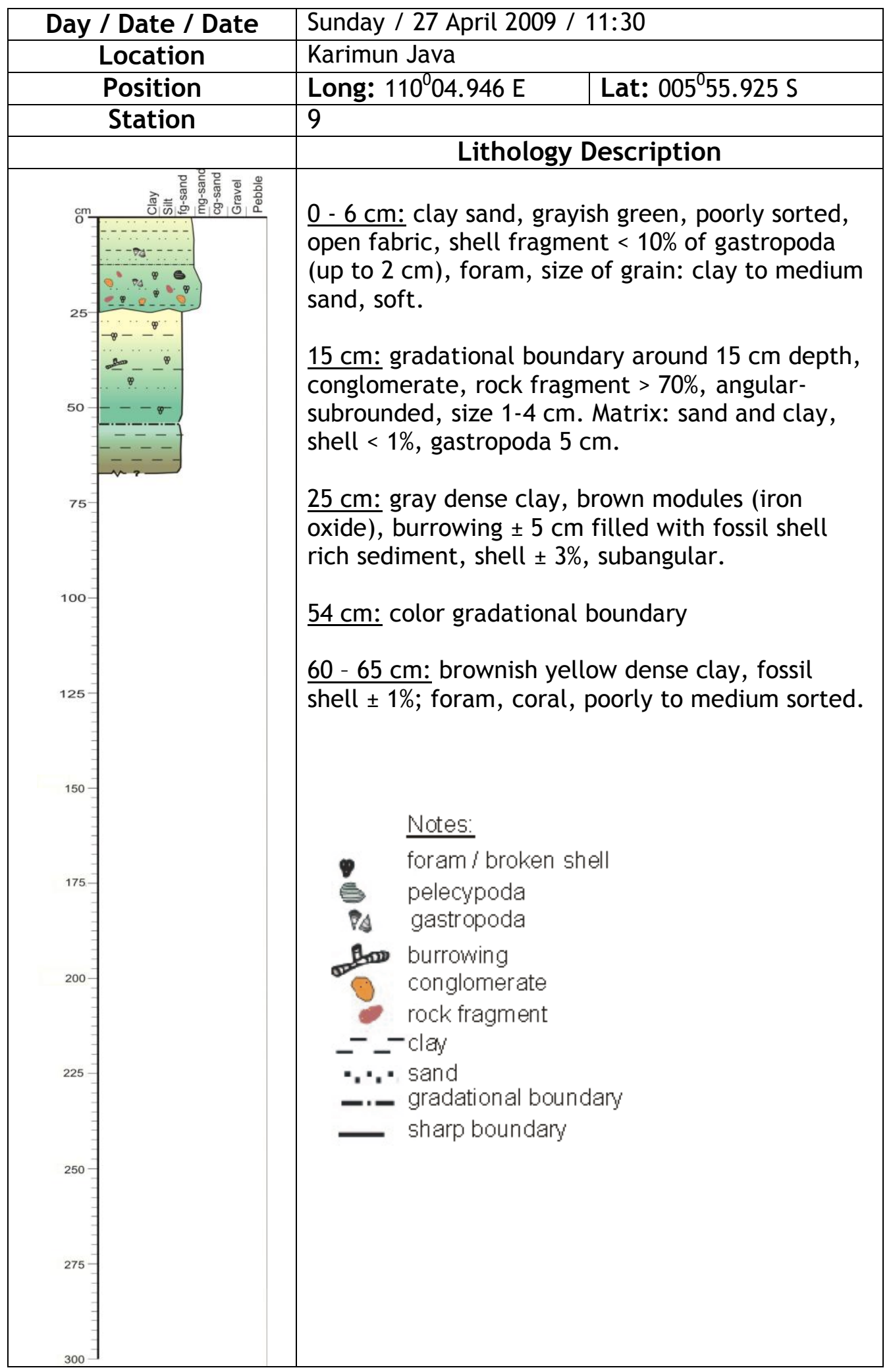




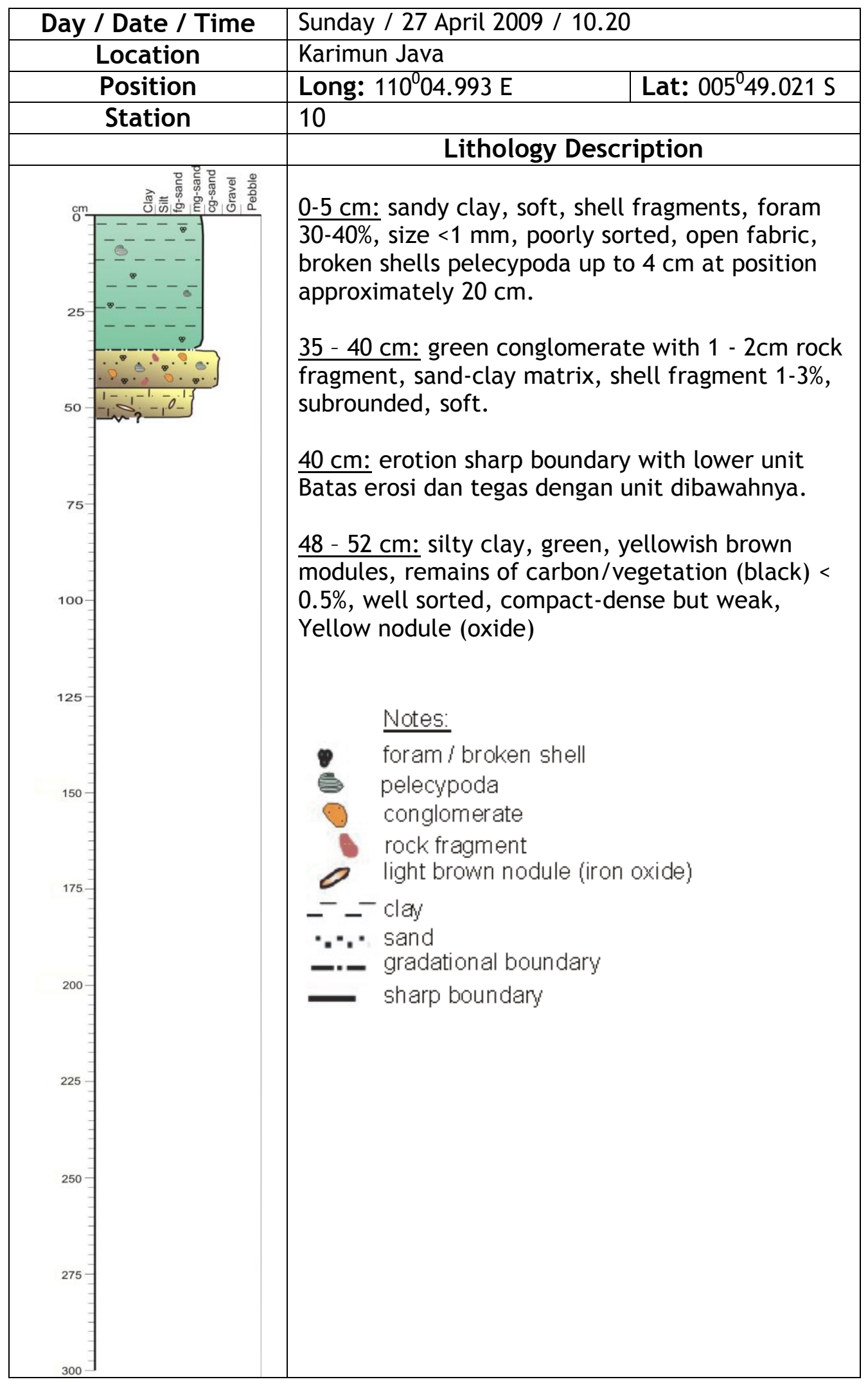




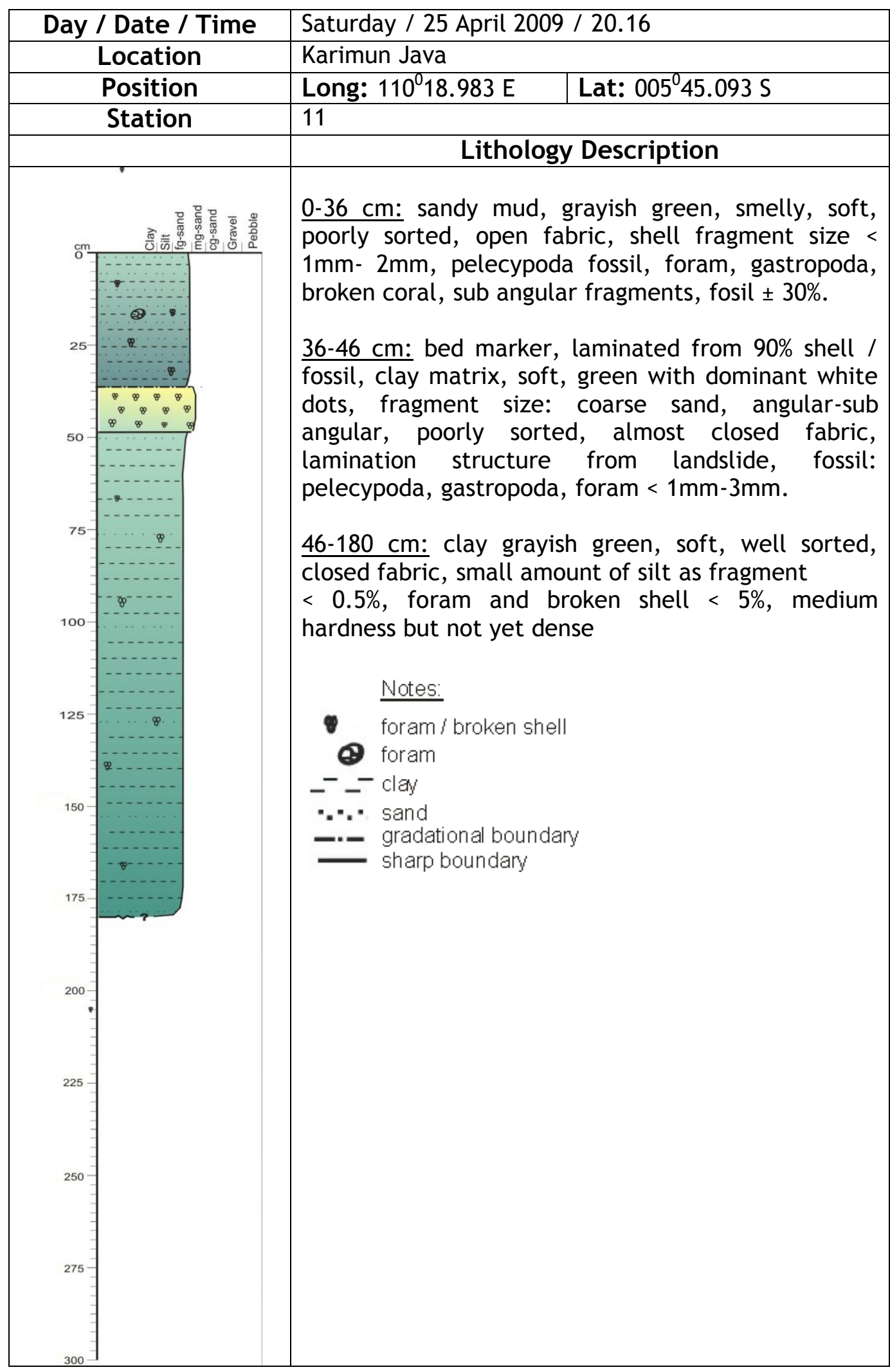




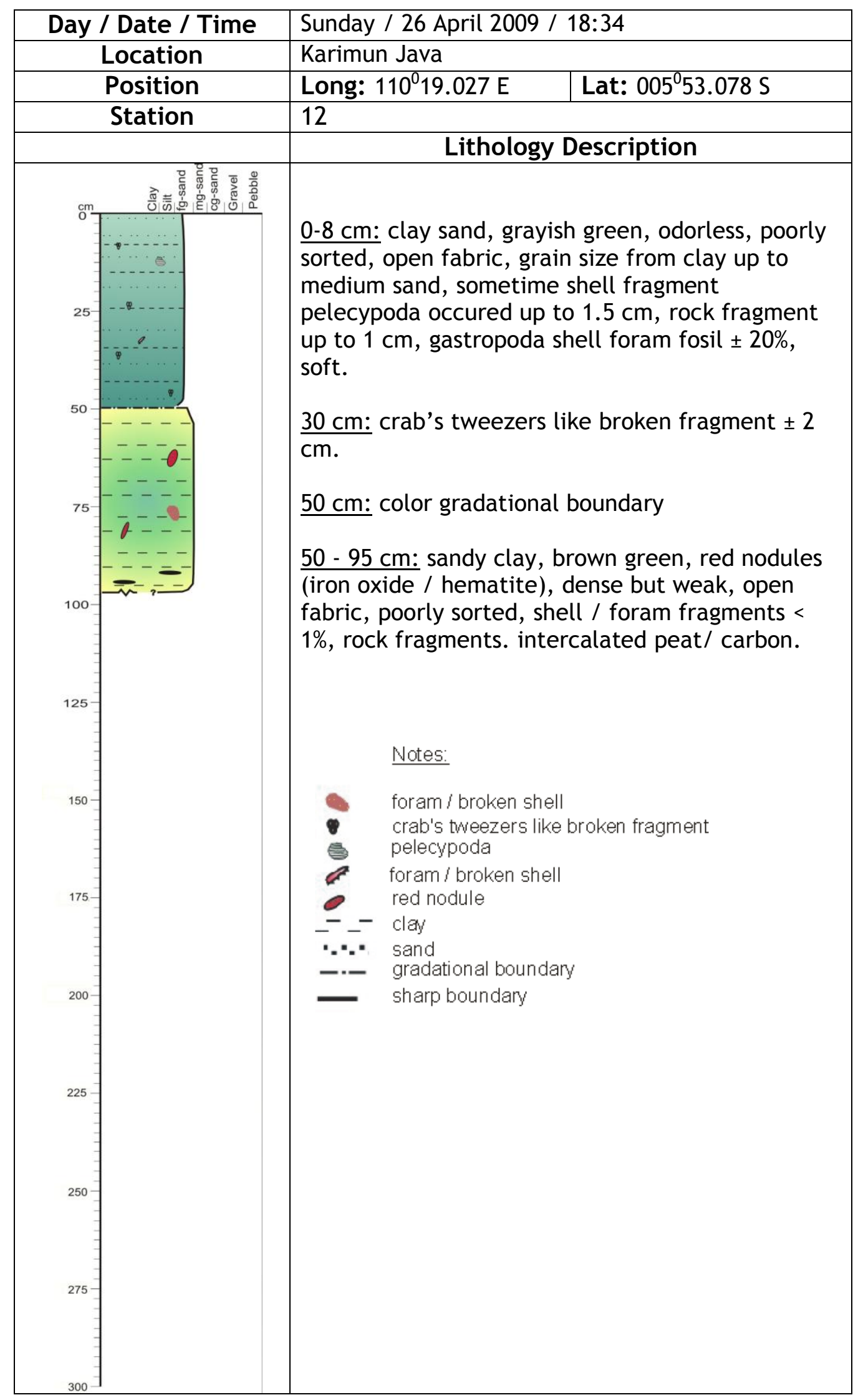




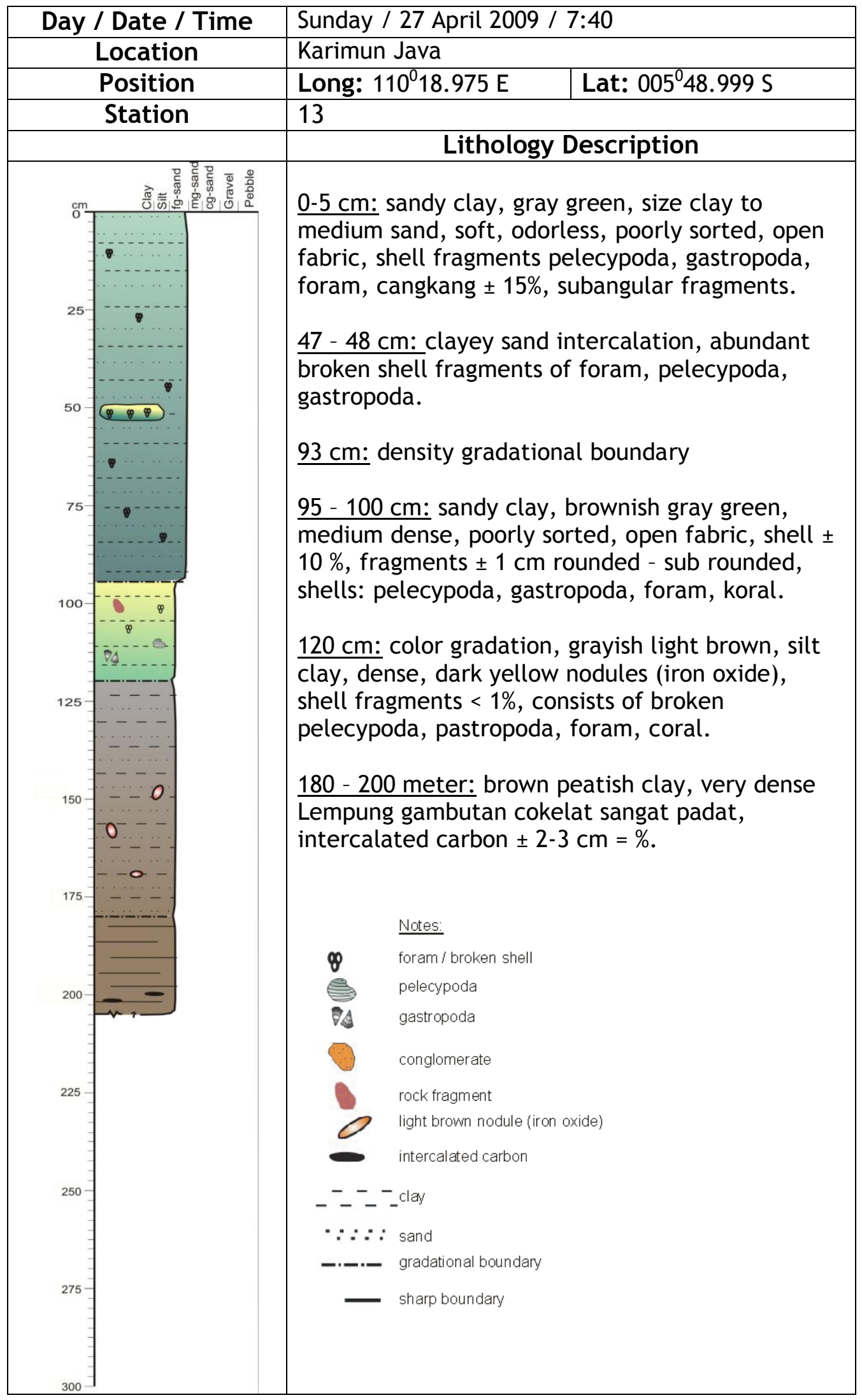

